\title{
CRISIS AND ADAPTATION (1884-1890S)
}

In 1870 the Cultivation System was officially abolished and private enterprise was allowed to operate more freely. However, tapping the wealth of the Indonesian archipelago proved difficult. The crisis of November 1884 had far reaching consequences for the business world of the Netherlands Indies, and involved some of the largest companies around such as Dorrepaal \& Co. Business interests in Amsterdam - together with the NHM and DJB - intervened and prevented a full-fledged collapse of the private economic sector. The threatening credit crunch could only be solved by an overhaul of the customs regarding credit extension which came down to financing long-term investments by incurring shortterm debts.

The 1884 crisis exposed the shaky foundations of the private economy. Many firms were forced to adjust their business strategy accordingly. The ties between commerce and capital became better guarded. The completion of this painful reorganization constituted a fundamental reassessment of the relationship between capital, commerce and agricultural enterprise. The crisis also affected the spending power of the indigenous population with great repercussions for the import side of the economy. Chinese and European enterprise with their mutual linkages suffered accordingly. Many Chinese tradesmen defaulted to the detriment of their predominantly European creditors.

\section{Economic Policy and Political Expansion}

The post-1870 liberal attitude governing economic policy would constitute the rather loose framework of entrepreneurial conduct until the economic crisis of the 1930s. In a political sense abstention was the official ideology behind Dutch colonial economic policy ever since 1841. Given the limited resources of the Dutch state, the country's colonial possessions were to be confined to Java. Dutch settlements outside of Java the so-called Outer Islands - were considered undesirable with costs 
outweighing the gains. Still, upon closer inspection a process of territorial expansion characterized the nineteenth century. ${ }^{1}$

Dutch expansion in the Indonesian archipelago proceeded in several phases. ${ }^{2}$ After the conclusion of the Java War $\left(1825^{-1830}\right)$, which left Dutch authority over the island undisputed, territorial ambitions slowly turned outward. The initial phase of expansion lasted until the early 1870 s and saw Dutch presence extended to West Sumatra, Bali, Lombok, Makassar (South Sulawesi), the Minahasa (North Sulawesi), South Kalimantan, Deli (East Sumatra) and the island of Belitung (see Map 1). At this point, commercial policy prevailed over political authority and expensive military intervention remained limited. Dutch private capital became involved in the Outer Islands during the 1850 s and 1860 os upon receiving concessions for mining and estate agriculture from local rulers which were subsequently endorsed by the colonial authorities.

The second phase lasted from 1873 until 1896 and started with the outbreak of the Aceh War in North Sumatra (Bossenbroek 2001; Van 't Veer 1969). Dutch colonial expansion became more determined, but overt military aggression did not extend much beyond Aceh. Expansion generally took the form of enforcing authority over territories that were claimed but not yet effectively controlled. Local economic and political interests frequently coincided to initiate (reluctant) colonial expansion (Fasseur 1979). Government economic policy fluctuated between restraint and intervention. Concessions, for instance, were authorized but could also be held up for years. Partly because the government could not guarantee the safety of men and property on remote sites, and partly because it anticipated a more expensive local administrative apparatus once a concession was granted. The exploitation of the Outer Islands' natural resources by private capital remained sluggish during this period which contrasted sharply with the situation in Java where private enterprise became feverishly active.

With the escalation of the Aceh War in 1896 the third and final phase of Dutch colonial expansion commenced. The deployment of massive

\footnotetext{
1 The history of Dutch imperialism in the Indonesian archipelago has been the subject of several studies. The most important are à Campo (1992, 2002), Kuitenbrouwer (1985), Lindblad $(1986,1989 a)$ and Locher-Scholten $(1994 a, 1994 b)$. See for a concise overview of the debates concerning Dutch imperialism Lindblad's contribution in Dick et al. 2002: 109-110.

2 The Historical Atlas of Indonesia by Cribb (2000) is an invaluable guide to the piecemeal process of Dutch territorial expansion. See especially Chapter 4, Paragraph 'Conquest and Annexation'.
} 
military resources and full-scale warfare lasted throughout the first decade of the twentieth century, by which time the Indonesian archipelago had been subjugated to Dutch rule. ${ }^{3}$ Only the western half of the island of New Guinea was spared colonial rule until the 1920s. Alongside the colonial administrators private European investors finally made their presence felt. The beginning of the twentieth century saw a massive influx of foreign direct investment into the Outer Islands (Dick et al. 2002: 93-106; Lindblad 1989c; Ricklefs 2001: 171-189).

The period under consideration here (coinciding with the second phase of territorial expansion) saw little evidence of growing economic activity in the Outer Islands. ${ }^{4}$ Certainly not comparable to the situation in Java. Towards the end of the nineteenth century private investment in the Netherlands Indies stood at approximately $75^{\circ}$ million guilders of which the overwhelming majority (at least $75 \%$ ) was invested in Java (Dick et al. 2002: 97; Furnivall 1944: 312; Kuitenbrouwer and Schijf 1998: 63-65). The political and economic centre of Java was far better equipped to reward new business initiatives. The island boasted a good infrastructure, a sufficient labour force accustomed to market production, as well as an experienced administrative system without pressing security concerns. The necessary means of communication and transport were either in place or being rapidly developed. The existence of roads, waterways, telegraph lines, shipping services, storage facilities etc. contributed to a favourable investment climate. Equally important was the presence of banks, insurance companies and trading companies.

Tapping relevant sources of expertise and support required considerable skills in social conduct and networking talent as the 'Western' business elite was small in number and closely-knit. ${ }^{5}$ The apex of the

3 Military conquest came at a price. Between 1875 and $1905 f 1504$ million ( $33 \%$ of colonial expenditure) was spent on army and navy. The Aceh War (1874-1901) cost about $f 300$ million (Diehl 1993: 197-198).

4 The establishment of the Deli Maatschappij in East Sumatra in 1869 is the proverbial exception to the rule. The organization of this tobacco estate emphasized large-scale production allowing for rationalization of processing and distribution and lower overhead costs, while setting a standard for consistent high quality. The company was an example of successful capital investment in the Outer Islands and ultimately launched a spectacular economic expansion of the region (Dick et al. 2002: 103; Thee Kian Wie 1977).

5 Exact figures are not available, but an indication is provided by Taselaar. Focusing on Dutch business interests, he discerns an elite of 143 persons divided over 129 families during the first half of the twentieth century. A distinction is made between a 'core' of 29 persons, who constituted the focal point of a network and the rest (Taselaar 1998: 49-57, 92-97). Bossenbroek distinguishes a 'core elite' of 31 persons in the Netherlands in 1900 (Bossenbroek 1996: 87-90). The 'Western' business elite of Java was probably of 
commercial world of Java in the nineteenth century consisted of an elite of well-to-do businessmen, who knew (of) each other and whose background (family, friends, acquaintances) provided (a sense of) security. This colonial business elite overlapped to a considerable degree with the business elite of the Netherlands and was well connected with political circles in both The Hague and Batavia. Merchants, bankers and brokers from Amsterdam figured prominently in this arena, although businessmen from The Hague and the Netherlands Indies also played their part (Bossenbroek 1996: 87, 113-114; Kuitenbrouwer and Schijf 1998: 82).

The relatively small (export) basis of the colony's economy made its business elite highly interconnected (Bossenbroek 1996: 87-89; Taselaar 1998: 49-57, 92-98). The NHM was the frontrunner in this respect. At the beginning of the twentieth century NHM's president C.J.K. van Aalst occupied eleven official positions at companies such as shipping lines and machine manufacturers. In addition, each of NHM's Directors performed similar functions at enterprises (Taselaar 1998: 58-62). DJB's network is also interesting. In 1902 the bank's six Directors held thirteen chairs in twelve different boards, either as executive or as supervising director. DJB was thus officially connected to five agricultural enterprises, three sugar factories, one bank as well as a cement, a mining and an insurance company (Kuitenbrouwer and Schijf 1998: 70-71). ${ }^{6}$

\section{The Organization of Trade}

Profit prospects made traders increasingly reckless in the years preceding the financial collapse of 1884 . World market conditions after 1870 were good and there was a strong demand for products from the Indonesian archipelago. Producing for the world market required working capital which was eagerly supplied by financial and trading firms. All over Java money poured in, accelerating the monetization of the economy and its concomitant demand for imports. These imports were supplied by wholesale traders, but could not be paid for by the retailers immediately. An intricate credit system, caused by the time lag between purchase and sale,

equal size. The analysis by Bosma and Raben of the planter's elite in Central Java in the nineteenth century seems to confirm this (Bosma and Raben 2003: 109-142, 250-261). See also Knight (1999 and 2006) for information related to Java's sugar industry.

6 Taselaar provides many more examples of this phenomenon by discerning several clusters of companies grouped around a single enterprise (Taselaar 1998: 31-98, especially $57-92,94-95)$. 
developed. According to Furnivall, it was conducted along the most risky lines (Furnivall 1939: 197; Van Laanen 1990: 254-255).

The inherent dangers were not completely overlooked. J. Hudig Dzn., Director of the Koloniale Bank (KB) and former employee of the NHM, is a good example of someone unable to change the course of events, although fully aware of the potential dangers. ${ }^{7}$ The KB started its activities in Java in 1881 and soon conducted business on a large scale. Despite warnings from the Commissioners and Directors Calkoen and Hudig in the Netherlands KB's head office in the colony quickly committed the bank for large sums. Frequently, the management in Amsterdam could only accept certain deeds as a fait accompli. ${ }^{8}$ Before the $\mathrm{KB}$ officially started its operations on Java, the bank's commitments amounted to $f 518$,000 in June 1881 , rising to $f 3,299$,000 in June 1882 , and reaching $f 5,997,000$ in June 1883 . On the eve of the crisis, the KB had already 'spent' about one million more than its total initial capital of $f_{5,000,000 \text {. }}$

On 30 September 1884 capital outlays in agricultural enterprises alone totalled $f 8,377,000$. Sugar $(f 5,712,000)$ and coffee $(f 1,621,000)$ accounting for $87,5 \%$ of the amount. These loans were advanced using the forthcoming harvests as collateral. Most planters could not operate unless they had sufficient working capital at their disposal. These so-called consignmentcontracts were universally used for that purpose (Djie Ting Ham 1926: 27-28; Potting 1997: 32, 65-66). Extending credit on these terms meant that the loan applicant agreed to give the products in consignment to the capital provider. The provider earned the right to sell the harvest of the debtor, receiving at least a $3 \%$ commission. This kind of contract was usually concluded for five years. ${ }^{9}$

Hudig became aware of the fact that the contracts were used to furnish working capital, but also to finance the establishment of new factories, or pay off other debts. In a commissioner meeting on 15 May 1882, he proposed lowering the interest rate of the bank from $7,5 \%$ to $6 \%$. He wanted to make the $\mathrm{KB}$ more interesting for financially sound companies in need of working-capital only, but not willing to pay such high interest. In his opinion companies needing more funds for additional purposes were oblivious to high interest rates, as long as they managed to get the money.

7 NA/KB 883: 17-18, 68, 73.

8 In general, long communication lines and the independent position of company representatives in the colony were an often heard-off complaint and could cause serious problems.

9 For the stipulations of a consignment contract, see Djie ting Ham (1926: 28). 
They would bet their cards on a good harvest and high market prices, enabling them to pay back the loan.

Hudig claimed that any decline in revenue from rents would be offset by an increase in commissions. If agreed the $\mathrm{KB}$ would confine itself to providing working capital only. Commissioners Fellinger and Hintzen, however, disagreed. They considered the extension of large sums part of the bank's business and were against a change in policy. Hudig had to back down although future events would prove him right.

Like Hudig, DJB was aware of the dangerous financing practices of the time. The situation had seemed to change for the better with the new legislation of 1870 . However, the new laws still curtailed the possibilities for Europeans to own land. The only viable option was to operate on the basis of a long-term lease. This was a significant improvement since Europeans had only been allowed to rent land for short periods of up to twenty years. However, real estate could be mortgaged, a practice widely used in the provisioning of capital. Land falling under long-lease arrangements could not, because there was a time limit on the use of it. DJB therefore underwrote the principle of only mortgaging land in ownership. Its example was followed by other financial institutions in the colony.

The resulting effect was one of expanding agrarian business with expanding credit needs that failed to correspond with existing credit facilities. The kind of money required proved to a considerable drain to the moneylenders' resources (be it trading company or bank). They dreaded having too much of their capital tied up, and put a rather short time-limit on any outstanding loan. Long-term commitments were thus accommodated by short-term loans to be repaid within months. Inevitably, loans had to be prolonged and/or renewed, leading to an ever increasing accumulation of debtors, creditors, and guarantors (De Bree 1928-1930: IIn1-119).

Immediately after the laws of 1870, DJB's Board of Directors decided not to allow advancements in agricultural enterprise. This decision did not work out the way as planned. DJB preferred to lend money on quickly disposable goods: so-called beleeningen. Other kinds of security - in essence anything judged too difficult to market - ought to be rejected. Nevertheless, DJB did not want to lose important clients. In the end, the agencies were advised to focus on traders' credit only, but it was left to their discretion to choose other secure possibilities (De Bree 1928-1930: II 121, 123).

In 1878 , this led to an internal conflict between the Board of Directors and the Board of Commissioners of DJB (Van Zwet 2004: 159-160, 162, 169). 
Commissioners strongly objected to the extension of working capital to sugar factories on the basis of mortgage and equity capital. The dispute could not be solved amicably and both parties turned to the government, who decided in favour of the commissioners. De Bree - dwelling on the timing of this conflict - discerns a possible conflict of interest in this matter (De Bree 1928-1930: II 123-133). Arguably, C.P. Lohr Jr., who had been appointed commissioner in 1877 , was the driving-force behind the protest. At the time, he was president of the Factorij in Batavia, the head office of the NHM in Asia and one of the principal competitors of DJB.

Although we could accuse Lohr of looking for an opportunity to obstruct the business operations of a competitor, there is an alternative explanation. In the period $1875^{-1879}$, the NHM incurred losses on its involvement in agricultural enterprise. Its profitability suffered and gave rise to dissatisfaction among shareholders. In 1879, the earlier mentioned Hudig was tasked to reduce the interests of the NHM in agriculture. After thorough inspection he started a clean-up of badly yielding business. In 1883 , NHM investment in agriculture stood at $f 6$ to $f 7$ million, down from $f_{11}$ to $f_{13}$ million in 1879 (Mansvelt 1924: II 404-405, 408, 415). It is therefore possible that Lohr operated in the best interest of DJB, having intimate knowledge of the NHM's vicissitudes. Regardless of Lohr's motivations, DJB would from now on steer a conservative credit course.

Only those who did not participate in any way with the financing of agricultural enterprise, could retain a truly independent position. This held true for the Nederlandsch-Indische Escompto Maatschappij (NIEM), the only Dutch bank in the Netherlands Indies, that confined itself to deposit banking (Djie Ting Ham 1926: 60). The same philosophy was adhered to by the English banks operating in the Indonesian archipelago: the Chartered Bank and the Hongkong and Shanghai Banking Corporation (HSBC).

\section{Credit and Agriculture}

Bankers and traders could respond to the credit needs of agricultural enterprise by providing long-term or short-term credit. After the crisis of 1884 this demarcation was much better understood. The Cultuurbanken (Agricultural Banks) came to focus exclusively on long-term commitments. The general banks strengthened their ties with the traders while keeping a lively interest in agricultural business on a short-term basis only. Such a clear distinction did not exist before the crisis (Helfferich 1914; Djie Ting Ham 1926: 26-38). 
Before 1884 advances were preferably given to enterprises deemed capable of repaying their debts within a short time. Consequently, attention focused on enterprises growing one-year crops like sugar and tobacco. In the case of crops that needed longer to harvest (e.g. coffee or tea) risks were evidently bigger. The duration of the contract was longer, a period in which more could go wrong. Pros and cons had to be weighed before entering into such a deal. This required more expertise and more monitoring once the contract was closed. Access to information in order to gain security was of great importance in this respect.

The consignment contract was the financial instrument used to cover short-term loans. The terms stipulated in this kind of contract strongly favoured the creditor. His risk was minimized by gaining the right to dispose of the product after the harvest. In addition, he sometimes demanded control over management and administration of the enterprise. Further security was obtained by mortgaging the buildings and the land (or its long-lease arrangement) and by acquiring the right to harvest the crops. Last, a consignment contract was always concluded for an extended period (usually five years). The creditor was entitled to cancel at any given time, whereas the debtor was only allowed to do so after a stipulated period of time, or otherwise obliged to pay a fine.

A solid company in need of a relatively small amount of cash for wages or transport would not accept such terms. Another popular source of short-term capital was the use of bills of exchange (Gimbrère 1924: $5^{0-56}$ ). In essence this constitutes an agreement between buyer and seller, whereby the buyer usually requests the signature of a guarantor. A bill of exchange reduces the buyer's risk, since a third party agrees to act as warrantor by accepting it. In so doing it greatly enhanced business trust, and contributed to the further development of commerce.

The use of bills of exchange signals the growing distance - both geographically and mentally - between the parties participating in the market. After all, when parties know each other and their solidity, they will trust each other enough to place and carry out orders without the backing of a third party (Gimbrère 1924: 7-9). The reliance on a third party only shifts the problem. People still have to ascertain the reliability and trustworthiness of one of the parties involved. If the financial soundness of the third party was known to depend heavily on future market price fluctuations or upcoming harvest results, the signature is subject to grave doubts and therefore worth less. Of course, there was always collateral in the form of the harvest or mortgaged buildings. But despite these provisions the element of risk remained. Harvest sales were uncertain, because of 
unexpected market price movements and the commission accruing to the moneylender remained uncertain. Rents from mortgages were fixed, but less attractive since property sales in case of default were more difficult to realize. Therefore, only $50 \%$ of the assessed value of property could be lent (De Bree 1928-1930: II 124).

What happened in the Netherlands Indies between 1870 and 1884 came down to a wrongful use of the credit facility described here. ${ }^{10}$ Agricultural enterprise offered the signature of its own head office as guarantor. These bills of exchange were known as 'pig on pork' paper. If the loan could not be paid, it was taken over and paid out by the holding-company (i.e. head office) itself. In other words, the request for credit was backed by a participant whose financial capabilities were at least partly reliant on the results of the enterprise that took the loan in the first place. In itself, this did not have to constitute a problem as long as this enterprise formed only a small part of the assets of the much larger holding-company. But if a significant percentage of enterprises belonging to the same holding-company all financed themselves in the same way the dangers were imminent. As soon as prices fell, plantations and factories could not break even. The mountain of debt came to rest on the head office, whose assets were tied to the price fall. With prices at an unprecedented low turnover shrank to such a level that even the costs of production could hardly be met. Remittances from the colony then successively declined. Upon maturity of the loans usually after six months - the head office had to default, causing the system to collapse.

\section{Credit and Trade}

Financing trade was conducted on slightly different grounds. A distinction has to be made between the financing of export, import and local trade. The export trade has attracted most attention in the literature. Import and local trade can be considered neglected subjects. The elusiveness of local trade - at least in the eyes of the 'Western' trading sector has certainly contributed to that effect.

Export traders bought their merchandise either straight from the producer or from intermediate traders. Often an advance was needed for production to take place. The money involved was furnished by the traders out of their own means, or by way of a bank in which case the

10 See Van Laanen (1990: 254-256), Djie Ting Ham (1926: 4-5, 29), De Bree (1928-1930: II 124, 128), Van den Berg (1907: 202). 
merchandise served as a guarantee. This kind of credit was called beleeningscrediet, i.e. loans on security. It was the most important way for an exporter to satisfy his need for cash (Djie Ting Ham 1926: 30-33). The procedure started with the exporter requesting the agent of a bank to grant him a loan. In return, he offered security by temporarily handing over the ownership of certain goods. These were stored in godowns and placed in the bank's custody. In case of payment problems the goods were at the bank's disposal.

In general DJB demanded a surplus value; i.e. the estimated value of the products should always be higher than the loan furnished. How much higher was determined by such factors as the reputation of the debtor and the characteristics of the pledged products. Products in high demand that were not perishable did not require such a high surplus when compared to products with the opposite characteristics. The rate of interest was usually pegged against the interest rate of $\mathrm{DJB}$ for products with comparable characteristics, albeit one or more percentage points higher.

The direct financing of commodity trade by providing credit on merchandise and/or securities required great caution with regard to the percentages advanced and the quality of the security. Since the price movement of tropical export produce was unpredictable, the surplus value demanded by DJB tended to be high. This affected the bank's competitive strength which was based upon low interest rates. ${ }^{11}$ Potential clients however not only considered the amount of interest they had to pay, but also valued the percentage advanced. Since other banks were more lenient in this respect DJB experienced significant competition in export trade finance (Van Laanen 1980: 34-35).

Beleeningscrediet was used above all by Chinese exporters and to a lesser extent by small European traders. The big European traders had large liquid assets which accounts for the fact that companies like Internatio, Jacobson/Van den Berg, or Geo. Wehry did not feature as debtors in the books of DJB. They rarely required a loan on security in which case they would usually turn to $\mathrm{DJB}$, whose interest rates for loans on export products (e.g. sugar, or rice) were consistently among the lowest. $\mathrm{DJB}$, however, could afford to be selective and only granted loans on strict conditions in an attempt to minimize risks. In the case of Chinese clients, DJB insisted on extra collateral by requesting them to mortgage real estate. As a result many did not qualify for loans and were turned down by the

\footnotetext{
11 See also Chapter 5, Paragraph 'Trading and Banking'.
} 
agents of DJB. They had to take their business elsewhere and frequently ended up at the doorstep of the NIEM, whose management was more inclined to speculative arrangements. This made the NIEM quite popular among the less solid enterprises. At the end of the 188 os the NIEM came to be known as a noodhaven (emergency harbour) for the less solid business enterprises. To be fair, it might be better to describe the NIEM as adventurous since its results in the period 1857-1902 were excellent, judged by the dividends paid out (Djie Ting Ham 1926: 6o-61, 64).

The import trade was subdivided into different sections through which the distribution of the goods took place. Wholesale trade was primarily undertaken by European importers. At least until the First World War when they practically monopolized the import of products. A partial explanation for this can be found in the fact that the trading links with Europe remained strong during this period, while direct trade with China and Japan was marginal. In $187464 \%$ of total imports in the Netherlands Indies derived from Europe. In 1910 imports from Europe stood at $52 \%$ against $1 \%$ from Japan. In 1909 imports from China constituted less than 5\% of total imports in the colony (Booth 1998: 211; Van der Putten 2001: 21-22; Post 1991: 18-20).

The actual distribution in the colony was undertaken by the intermediate trade or 'second hand', monopolized to great extent by Chinese traders who passed the products on to the 'third hand' and from there to the 'fourth hand'. Like the exporters, the wholesale import trade had to rely on credit to conduct its business. The loan on security also served to satisfy the need for cash in the import trade (Djie Ting Ham 1926: 34-36). However, the security principle was more difficult to uphold for the creditors. The import firms were advanced considerable sums with their commodities as collateral. These remained in the debtor's custody in order to sell. The sale of goods took place while stocks were being replenished with new imports (partly serving as collateral as well). The resulting fluctuations of stock made it extremely difficult for the creditor to be sure of the value of his collateral.

Extending credit on these terms implied a high degree of trust in the reliability of the applicant. Potential irregularities were difficult to prevent and to ascertain. As a result, the interest rate on import loans was higher than on export loans. The nature of import products also contributed to this outcome. The composition of imports was more diverse and consisted of products more difficult to value than those of export products.

A good example is the disagreement between the Board of Directors of DJB and its agent in Surabaya in April 1884 concerning beleeningen on 
imported goods. ${ }^{12}$ At the end of March 1884 the agent in Surabaya had agreed to credit transactions with l.J. Brandon \& Co. (one hundred barrels of flour), J.W. van den Brink \& Co. (paper, playing cards, eau de cologne, knifes, sardines, scissors, etc) and the Maatschappij 'de Volharding' (ironware). According to the Directors DJB policy had always been not to commit to this kind of security since it was too difficult to market profitably. Therefore they failed to understand how the Surabaya agent had come to conclude these deals on such basis. A telegram was sent asking for an explanation.

Three weeks later, the Board of Directors was given a report drawn up by DJB's President N.P. van den Berg. ${ }^{13}$ It was read with great interest and discussed in the early afternoon of 26 April 1884 . Van den Berg admitted that a number of products were not desirable as security and would have been refused under normal circumstances. However, he pointed out that these goods constituted only a tiny portion of total security offered. Better marketable stock had been sought and found, but would have entailed additional costs since these commodities were stored elsewhere and would have had to be moved. He added that most of the questionable goods were already sold and would be delivered upon payment. Additional security was provided by the appointment of a bewaarder (keeper) instructed to supervise the goods in his custody. ${ }^{14} \mathrm{He}$ was required to keep an inventory with an exact specification of the stored items and could only release them after payment of the loan and upon written authorization from the agent of DJB. In the end, the loans were approved except for Maatschappij 'de Volharding' whose goods were not safeguarded properly. The agent was instructed not to prolong this particular loan and advised to make sure that some of the other articles did not serve as security too long.

Wholesale traders had to give advances to the 'second hand' in order to guarantee the sale of their products. They were given promissory notes (IOU's) in return promising to pay a certain sum of money within a certain time. As long as the intermediary trader managed to find an outlet for

12 BI/DJB 52 No. $1: 2$.

13 BI/DJB 52 No. 4: 13, 18-21, 24.

14 A description of the function of bewaarder (keeper) can be found in Vleming (1926: 149). The job required little education with daily activities confined to the counting and recounting of stocks. The results were written in inventory lists which had to be regularly submitted to the bank. Employment as bewaarder seems to have been poorly paid, while earning little status in colonial society. This kind of administrative work was often done by those belonging to the lower strata of society, e.g. Indo-Europeans, or people that had come down in the world. See for an example of the duties and performance of one unfortunate bewaarder the paragraph 'Sing Liong \& Co.' below. 
his goods, the promissory notes could be considered liquid and he would be able to pay back within the stipulated period. When no sales had taken place once the expiry date had arrived, there was only one thing left to do: to prolong the loan by replacing the old promissory note by a new one. In essence, the distribution trade depended completely on the credit extended by the wholesale importers. The latter had to have considerable means, or they would not be able to give advances to their clients, while keeping a large stock to supply these same clients.

Although this generally held true, the amounts involved were so large that many wholesale importers frequently experienced the need for cash when their own assets were tied up in stocks and advances. To get out of this situation, they would offer promissory notes in their possession to the bank as security for a short-term loan. In the earlier mentioned case of the questionable security Van den Berg stated:

The countless defaults among the intermediate traders are making many an importer hesitant to dispose of his goods, and rather than giving his goods against promissory notes and discounting these at the bank, they retain these for themselves, and try to acquire as many funds [i.e. cash] as needed by pledging the goods at the bank themselves. In the given circumstances, it is advisable from our point of view to facilitate these kinds of operations, in so far this can be done properly considering our own security $[\ldots] .^{15}$

By accepting promissory notes, bankers took over the burden of financing the intermediate trade from the wholesaler. This had important consequences. Not only the reliability of the importer had to be considered, but also that of the distributor, whose IOU was waved by the former in the banker's face. Van den Berg's assessment of the situation in Surabaya shows that the wholesale importers doubted the liquidity of the promissory notes given by their customers. They were not prepared to risk tying up their assets and being unable to pay their own bills, because of the banks' refusal to honour any IOU's in their possession.

Since the distributor was often a Chinese, the banks wanted to be well informed about the situation in the so-called Chineesche Kamp (Chinese quarter). Who was backing whom? What other businesses were these Chinese in? Did they have contacts with other banks? Therefore the banks checked the soundness and liquidity of the offered promissory notes thoroughly. To reduce risks, surplus value was insisted upon. Small debtors received only $60-70 \%$ of the promissory note, while bigger clients could

15 BI/DJB 52 No. 4: 19. 
get $80-90 \%$. The banks would also spread the risks by refusing loans when promissory notes carried the same signature.

Last but not least, there was the question of the contract's running time. The fierce competition between the import houses for a share of the market took place at the price level of the products, but also by giving clients larger advancements and granting them longer terms of payment (Fromberg 1926: 619, 623-625, 627; Alting Mees 1884). The banks tried to oppose this tendency by favouring short terms of payment. On their instigation, the terms of payment that used to run for $4-6$ months were slowly reduced to periods of $1-3$ months during the last quarter of the nineteenth century. This process, however, saw frequent setbacks owing to the competition among European firms which could lead to a temporary relaxation of credit terms in order to sell their stocks (Gimbrère 1924: 62; Jonker 1996: 115$){ }^{16}$

\section{The Onset of the Crisis: Sugar and Coffee}

In 1884 bankers, traders and planters never suspected that the foundation on which their business rested was so fragile. It took a crisis of unknown proportions to expose the tangle of existing capital arrangements. The crisis provoked a thorough clean-up and unravelling of the existing ties and resulted in more accountable ways of conducting business. This left the export/import business better equipped to withstand the many convulsions associated with the dynamic world of commerce.

The economic crisis of 1884 has gone by different names. Two characterizations most commonly encountered are 'Banking Crisis' or 'Sugar Crisis'.17 Regardless of the labels attached to it, it was a sudden and extremely violent shock to the commercial establishment of those days. Evidence of its impact can be found in the repeated references to the

16 The same trend occurred in Singapore. In the 1820 s credit was extended for two months only, but this period had gradually become three months and eventually six months. In order to put a check on fraudulent practices in the credit system, the Singapore Chamber of Commerce decreed in $185^{2}$ that none of its members should grant credit for longer than three months. After several high-profile bankruptcies ascribed to the indiscriminate granting of credit to Chinese merchants, the Singapore Chamber of Commerce would urge its members in $\mathbf{1 8 6 4}$ to further reduce the term of credit from three to two months (Wong Lin Ken 1960: $165^{-166)}$. See for more details concerning the situation in Singapore Box 2 in Chapter 4.

17 This crisis was not confined to Java alone, but part of a protracted worldwide decline in agrarian prices between 1880 and 1900. See for the Dutch situation Jacobs and Smits (2001), Van Zanden (1985: 246-252, especially 248), Van Zanden (1987: 52-56). 
event, many years after it had been overcome. ${ }^{18}$ It came to form part of the collective memory of generations of businessmen.

What triggered this chain of events, and what does it tell us about the fundamentals underlying the commercial world of Java at the time? The key factor initiating the process of default was the sudden fall in the price of sugar. Most primary commodity prices declined in these years, but of the tropical products none was hit as hard as sugar. In 1884 the price dropped by almost $40 \%$, a major blow to sugar producers all over the world. ${ }^{19}$ This decline was not an entirely new phenomenon. ${ }^{20}$ It had been experienced by sugar traders since the 1860 s, but until 1880 it was a relatively marginal phenomenon. Besides, the sugar market was notorious for its price fluctuations.

The downward trend of the sugar price had its roots in the worldwide growing supply of both cane and beet sugar which was strongly encouraged by an ever-increasing demand for sugar (see Table 3.1). For centuries cane sugar had been the only sweetener available for mass production and consumption. Technical progress, however, made the mass production of

Table 3.1. The growth of Java and world sugar production in metric tons (x 1000), 1860-1890.

\begin{tabular}{|c|c|c|c|c|}
\hline \multirow[b]{2}{*}{$1860^{*}$} & \multirow{2}{*}{$\frac{\text { Java }}{130(100)}$} & \multirow{2}{*}{$\frac{\text { World (cane) }}{1376 \quad(100)}$} & \multicolumn{2}{|c|}{ World (beet) } \\
\hline & & & $35^{2}$ & $(100)$ \\
\hline 1865 & $142(109)$ & $1506(109)$ & 681 & (193) \\
\hline 1870 & $176(135)$ & $1662(121)$ & 939 & $(267)$ \\
\hline 1875 & $203\left(15^{6}\right)$ & $1816\left(13^{2}\right)$ & 1377 & (391) \\
\hline 1880 & $221(170)$ & $1883(137)$ & 1857 & $(528)$ \\
\hline 1885 & $387 \quad(298)$ & $2300(167)$ & 2172 & $(617)$ \\
\hline 1890 & $423(325)$ & 2597 (189) & 3680 & (1045) \\
\hline
\end{tabular}

* $1860=100$

Sources: Creutzberg (1975: 63-76, 141-143), Leidelmeijer (1997: 39-42, 324-326).

18 Countless memorial volumes testify to this assertion. To name but a few: De Bree (1928-1930: II 232-262), Mansvelt (1924: II 415-418), [Internatio] (1913: 14-19); [Internatio] (1938: 19-22), Colenbrander \& Stokvis (1916-1917: I 144-147).

19 Albert and Graves (1984: 1-2). For a graphic representation of the fall of the sugar price, see their volume (Figure 1.1 and 1.2 on p.2).

20 This section is partly based on the dissertation of Bakker $(1989: 44-51)$. See for a brief introduction also Albert and Graves (1984: 1-9). 
beet sugar in Europe a viable option from the $1860{ }^{21}{ }^{21}$ In 1870 the worldwide production of cane sugar was still about twice that of its competitor. But in 1883 the production of the two kinds of sugar were virtually on a par. After 1888 the production of beet sugar kept growing at a faster pace than its tropical variant. Nonetheless, cane sugar production in the period 1860-1890 displayed quite a remarkable growth, considering that the industry was far more mature (Claver 1995: 15-16, 55).

The production increase on Java was realized first of all by establishing new sugar factories. Between 1882 and 188418 new sugar factories were established (De Bree 1928-1930: II 232; Rush 1990: 179). Second, the threatening competition of beet sugar stimulated the planters to improve the profitability of their enterprises. Around 1860 they started to enlarge and modernize their plantations and factories. Consequently, output expanded and by 1882 the production of the Java sugar industry had more than doubled compared to 1870 (Tio Poo Tjiang 1923: 20). In 1884, total production of Java sugar amounted to $6,493,000$ picols, ${ }^{22}$ an increase of over $75 \%$ when compared to 1876 when total volume stood at $3,700,000$ picols (De Bree 1928-1930: II 232).

The growing supply of sugar had a downward effect on the price. This encouraged producers to put even more sugar on the market. It was the only way of making a profitable return on their investments. Since producers could not influence the market price individually, every supplier had to conform to price movements on a huge, anonymous world market. (See Table 3.2 for an indication of the relative position of Java sugar.) But sugar production remained profitable. Before 1884 participation in the industry seemed a sure bet. The sugar manufacturer's cost price lay at $f$ 10 per picol, whereas even the lower quality sugars were bought by the trading companies for $f_{12,75}$ to $f 13$ per picol. (De Bree 1928-1930: II 232 ). With profit margins of $25-30 \%$ it is hardly surprising that the expansion of output was on everyone's mind.

It was not until 1880 that people began to feel uncomfortable with the sugar market. Even experts could only guess the rationale behind the continuing fluctuations. Sugar traders such as Rueb \& Co. in Rotterdam admitted to this frankly. When reviewing the sugar market of 1883 they wrote that all statements predicting deficiencies in the harvests had been totally unfounded. Never before had world production been so large.

21 The historical development of beet sugar production in Europe, and more specifically the Netherlands, in relation to the production of cane sugar is described in Claver (1995: 16-23).

22 picol = 61,76 kilo (Van Schendel 2000: 110). 
Table 3.2. The share of Java sugar in world production, 1860-1890.

\begin{tabular}{lccrcc}
\hline & Java* $^{*}$ & $\begin{array}{l}\text { World* } \\
\text { (cane) }\end{array}$ & $\%$ & $\begin{array}{l}\text { World* } \\
\text { (cane + beet) }\end{array}$ & $\%$ \\
\hline 1860 & 130 & 1376 & 9 & 1728 & 8 \\
1865 & 142 & 1506 & 9 & 2187 & 6 \\
1870 & 176 & 1662 & 11 & 2601 & 7 \\
1875 & 203 & 1816 & 11 & 3193 & 6 \\
1880 & 221 & 1883 & 12 & 3740 & 6 \\
1885 & 387 & 2300 & 17 & 4472 & 9 \\
1890 & 423 & 2597 & 16 & 6277 & 7 \\
\hline
\end{tabular}

* in metric tons (x 1000)

Sources: Creutzberg (1975: 63-76, 141-143), Leidelmeijer (1997: 39-42, 324-326).

The logic behind all this exaggeration? To tell the truth, we don't understand a bit of it! $!^{33}$

They concluded by lamenting that all the mistrust had only caused prices to fall to the lowest level in many years.

The standard quality ${ }^{24}$ of Java sugar, which touched $f 19$ per picol in 1877, dropped to $f_{15}$ per picol in 1883 (Furnivall 1939: 196; Tio Poo Tjiang 1923: 20; De Bree 1928-1930: II 232). This drop coincided with the moment that the world production of beet and cane sugar had reached equal size. Whether this knowledge constituted a psychological turning point is uncertain. Whatever the cause, buyers and suppliers reacted without restraint and tried to get rid of their stock, resulting in an unprecedented and dramatic fall in price (Bakker 1989: 50-51). In January 1884 the price had dropped to $f_{13}$ per picol and fell to $f 11$ in July. During the harvest of 1884 the price of Java sugar kept falling to $f 8$ per picol (Furnivall 1939: 196; Tio Poo Tjiang 1923: 20; De Bree 1928-1930: II 232-233). In relative terms the price of sugar in that year fell by $23 \%$ in Batavia and nearly $29 \%$ in London. These percentages are the best indicators for the seriousness of the crisis, especially since London had become the most important market for Java sugar after the Sugar Act of 1870 and would remain so until the 189os (Korthals Altes 1994: 17, 79, 93).

${ }^{23}$ Cited in Bakker (1989: 50). See also Van den Berg (1907: 208, Note 1).

24 The price of sugar depended upon the level of purity. In 1839 the NHM devised a method of rating 18 kinds of sugar by colour of which 1 represented the 'standard' quality (Mansvelt 1924: II 167-168). 
Judging from events in other sugar markets such as Amsterdam, Antwerp and Paris, the collapse was a shared phenomenon. Remarkable since the Paris and Antwerp sugar market were virtually closed for foreign sugar, because of significant import duties. The London and Amsterdam sugar market did not impose any kind of protection. The effect of crises could therefore be felt immediately. Nevertheless, there was not much difference in price movements in the respective markets. ${ }^{25}$ The sudden fall in prices was so marked that it threatened a total breakdown of the whole economic system in Java (Furnivall 1939: 196). Sugar was the most important export commodity of colonial Indonesia and its domination of Java's estate economy meant that the impact of the crisis became widespread.

Sugar had only recently overtaken coffee as the major export earner. ${ }^{26}$ However, coffee remained of great importance for the economy and it was not until the 189os that the struggle for first place as the country's prime export earner was decisively won by sugar (Brown 1997: 21; Korthals Altes 1994: 79). Coffee underwent its own crisis in the years immediately preceding 1884 . From the late 1870 s the coffee leaf disease seriously damaged Java's coffee plantations. Harvests were minimized or completely obliterated and production had fallen. ${ }^{27}$ In addition coffee cultivation became even less profitable after the price of coffee started to slide from 1877 onwards, culminating in a major price fall in 1881/82. Between 1877 and 1883 the price of coffee fell from $f 60$ to $f 30-35$ per picol. ${ }^{28}$

Together coffee and sugar were of immense importance for the economic prosperity of Java. ${ }^{29}$ Huge sums were invested in cultivation and trade involving ever bigger and usually interconnected interests. An increasing number of people, all reckoning to be rich within years, scrambled for a piece of this pie. ${ }^{30}$ Everyone seemed to profit. Despite wavering

25 Bakker (1989: 46, 51).

26 The figures below show the share in export earnings of the largest commodity (Booth 1998: 208).

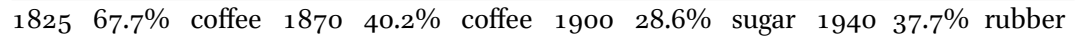
$\begin{array}{lllllllll}1850 & 36.1 \% & \text { coffee } & 1885 & 45.4 \% & \text { sugar } & 1925 & 32.6 \% & \text { rubber }\end{array}$

27 This can be illustrated by the example of the two coffee plantations 'Mangan Ardjo' en 'Mangan Simo' in Central Java, owned by A.J. Boers. In 1883, these two coffee lands produced 3,804 picols of coffee against 313 picols in 1884 (BI/DJB 52 No. 92: 493).

28 See Furnivall (1939: 196), Ricklefs (2001: 162), Korthals Altes (1994: 17), De Bree (1928-1930: II 232).

29 See Bulbeck et al. (1998: Chapters 4 and 5) for the importance of coffee and sugar in Southeast Asia.

30 This was not altogether improbable. When discussing the position of DJB debtors in Surabaya in July 1871 , the following was said about J.H. Fuchter, a notary of profession with 
commodity prices, the early 188 os were prosperous years for Java. In the wake of the Agrarian Law of 1870, which opened Java to private exploitation, commercial agriculture continued to expand.

Coffee and sugar can be considered true exponents of the agrarian export economy. These and other export commodities had brought the government of the Netherlands Indies huge revenues. Revenues that were largely remitted to the mother-country. The economic development and resulting great wealth of the Netherlands were for a substantial part founded on the efficient exploitation of - above all - Java's resources (Van Baardewijk 1993; Fasseur 1975: 20-21, 37-42, 118-128, 200-205). At the same time, the dependence on a few agrarian exports set the stage for problems that started in the beginning of 1884 and unfolded from the middle of September.

\section{Beginning of the Crisis}

What events finally tipped the scale and plunged the commercial world of Java into a prolonged crisis? At the beginning of 1884 optimism still reigned, but with a depressed sugar market and with the sugar price at an all-time low (according to Rueb \& Co.) it did not take much to shake confidence. In February 1884 - with the sugar price down to $f_{12}$ - sugar traders C. Bahre \& G. Kinder went bankrupt. They had been in the import/ export business since 1848 and were among the bigger traders. Their downfall caused quite a stir. ${ }^{31}$ DJB-President N.P. van den Berg discussed the situation on 21 February 1884 and drew the attention to the difficult position of another renowned firm, Martin Dyce \& Co. in Surabaya. This company too was in the sugar trade and had advanced substantial sums for that purpose. N.P. van den Berg anticipated big losses considering the current market conditions. ${ }^{32}$ And so it did, because on 29 February 1884 the headquarters of Martin Dyce \& Co. in Glasgow sent the following telegram to its agent MacColl:

substantial interests in the cultivation of sugar: "Probably J.H. Fuchter will become a man of fortune in due time, but for the moment everything still has to be paid out of the sugar" (BI/DJB 39 No. 76: 64).

31 Bahre \& Kinder were also active as shipping and insurance agents and had acquired a good business reputation. In the late 1850 and 1860 os members of this German firm were listed as (honorary) consul for Denmark and several of the German states (Saxony, Bremen, Oldenburg) (Merrillees 2000: 6o-61).

32 BI/DJB 51 No. 48: 200-201. 
Have suspended payment balance books at all branches 29 February. Give preference to nobody. Suspend operations until you hear from us. Must hand over nothing $[\ldots]$.

The next month Martin Dyce \& Co. declared itself bankrupt. ${ }^{33}$ Like Bahre \& Kinder, it had been in the import/export business for years (at least since the 186os). With the collapse of these companies, business confidence - aggravated by the persisting downfall of commodity prices in general and sugar prices in particular - started to melt away. ${ }^{34}$

Worried about the unfolding situation DJB concluded that a careful review of the bank's engagements in Central Java and East Java was called for. ${ }^{35}$ Letters with instructions and requests for additional information were sent. In April 1884 N.P. van den Berg left Batavia for Semarang and Surabaya. This visit formed part of the regular inspection of the branch offices of DJB as a means of monitoring its agents. However, Van den Berg also assessed the position of the sugar business in this part of Java. His findings were not encouraging. He encountered a very depressed mood among sugar manufacturers and traders. Regardless of the price there was hardly any inclination to trade and people doubted whether the trading companies could purchase all the available sugar, estimated by N.P. van den Berg at five million picols.

In other words, the purchasing power of the export sector was judged to be insufficient. Traditionally, each sugar enterprise sold the bulk of their production to exporters in Java (Korthals Altes 1994: 79). ${ }^{36}$ This system was maintained until 1917 when a sharp price fall led producers to set up an association - the Vereenigde Javasuiker Producenten (VJSP) - in order to prevent prices from sliding again. It seems there was no such response during the crisis of $\mathbf{1 8 8 4}$. However, we learn from Van den Berg's account that two so-called sugar unions (suikerbonden) had been established in Central Java in 1884. According to Van den Berg, the sugar manufacturers had become convinced that they themselves had to find buyers abroad. For this purpose they combined under the guidance of experienced trading enterprises: i.e. Dorrepaal \& Co. and Internatio.

The agreement between Internatio and various producers shows how the sugar industry tried to provide for security. ${ }^{37}$ Under the arrangement

\footnotetext{
33 BI/DJB 51 No. 50: 208; BI/DJB 51 No. 52: 232.

34 See Mansvelt (1938: Appendices 2 and 3).

35 The following paragraphs are partly based on a report submitted by N.P. van den Berg on 26 April 1884 (BI/DJB 52, No. 4: 15-27).

36 See also BI/DJB 52 No. 4: 25 .

37 BI/DJB 52 No. 4: 25-27.
} 
the participants' sugar was pooled in order to be sold by a common sales department under the 'right' conditions. To enable the planters to continue their business, Internatio would advance money to the participants upon each delivery which left the sugar in possession of the company. The sales department was run by Internatio. The planters' interests were safeguarded by the establishment of a committee of three that would take care of day-to-day affairs and convene alternately in Surabaya and Semarang. It was specified that a representative of the producers would be seated in the committee. In case of disagreement his decision would settle the matter. The inspection of the sugar - in order to determine its value - would be done objectively by assigning an independent inspector to perform this task. If need be, the planters' representative was allowed to act as such. The planters could appoint a representative in Rotterdam to consult with Internatio's Directors about sales policy.

It should be kept in mind that this cooperation was forced upon the participants because of exceptional economic circumstances. Normally, the interests of traders and planters tended to clash, above all concerning the value of the delivered sugar. It was the buyer/exporter who decided how much he was willing to pay for the sugar and he himself carried out the inspection. According to the planters their sugar was consistently undervalued. Arbitration was possible, but this meant turning to the trader association (Handelsvereeniging) in which the big sugar exporters occupied a dominant position. When in 1883 the sugar price steadily declined, sugar traders tried to hedge against a further price fall by severely 'cutting' the value of the marketed sugar. In September 1883, manufacturers complained that the price of the same quality of sugar was now $f 1,5$ to $f 2$ less than the year before. ${ }^{38}$

Although hopes were high, the proposed sugar union did not succeed. Too many actors in the business were left outside and no influence could be exercised on market prices. Even a completely unified Java sugar industry would have had a weak position vis-à-vis the world market with only $6 \%$ tot $9 \%$ of total world sugar production in the period $1880-1885$ (see Table 3.2). In August 1884 another big player in the field started to tumble and suspended payments. Erdmann \& Sielcken, active in Java's commercial trade since 1875 , managed to resume trading operations after reaching an agreement with its creditors. By paying $20 \%$ of outstanding debts the firm was given complete discharge from liability. A modest new capital

38 NA/KB 883: 42-43. 
investment of $f 100,000$ enabled the company to make a successful restart (Schmiedell 1924).

In early November 1884 Dümmler \& Co. threw in the towel as well. This bankruptcy seems to have been the final confirmation that any rescue attempt for the industry was doomed to fail. Dümmler \& Co. had been in business at least since 1843. Its involvement in sugar dated back many years and it was counted among the three most important sugar exporters in Surabaya. ${ }^{39}$ Like any other trading firm, Dümmler \& Co. had borrowed heavily in order to secure the delivery of sugar from the producers.

The assets of both traders and planters were relatively small compared to the huge sums necessary to harvest, manufacture and market the sugar. To provide the necessary working-capital (werkkapitaal) of the planters advances were made, to be repaid when the sugar was finally sold. The time lag between the extension of the loan and the final repayment was therefore considerable. Dümmler \& Co. had sought to overcome this problem by asking the banks for credit. This was common practice and the Nederlandsch-Indische Handelsbank (NIHB) was among those that had agreed to Dümmler \& Co's request for capital. With Dümmler \& Co. bankrupt, the extended loan of $f 400,000$ could not be redeemed and had to be written off. In a normal situation, NIHB's capital reserves would have sufficed to absorb this write-off. But times were far from normal.

The NIHB needed the support of DJB from late June 1884 when its agent Van Heukelom admitted to a temporary shortage of liquid assets because of the sugar crisis. A credit of $f 1,500,000$ was given on the personal recommendation of N.P. van den Berg. An additional credit of $f 600,000$ was given in September 1884. Desperate for funds the NIHB tried to strengthen its position by raising a debenture loan of $f 2,954,000$. Less than $f 500,000$ was subscribed to, and the attempt failed (De Bree 1928-1930: II 235). ${ }^{40}$ By now, unrest became widespread. Trust in the stability of even the biggest institutions in the Netherlands Indies started to wane. When the KB ran into similar problems at the end of October 1884, the NHM turned down its request for help. On 1 November 1884 KB-agent Lohr informed N.P. van den Berg of the extremely serious situation. Within days head office in Amsterdam would have to default unless DJB agreed to operate as 'lender

39 NA/KB 883: 42-43; BI/DJB 39 No. 66: 9-10; Mansvelt (1938: Appendices 2 and 3).

40 See also BI/DJB 52 No. 47: 172. 
of last resort'. Director Hudig of the KB, a personal friend of N.P. van den Berg, was confident that DJB would help out. In his own words:

President Mr. N.P. van den Berg is extremely well-disposed towards us and will be glad to collaborate. ${ }^{41}$

Lengthy deliberations among the Directors of DJB commenced. The KB was in effect bankrupt. Its assets were tied up and could not be made liquid on short notice. Acquiring additional funds by means of a debenture loan was the only option, but permission could only be granted in a shareholders' meeting. Such a meeting could be convened, at the earliest, at the beginning of December.

On 5 November 1884 DJB agreed to provide a credit of $f 200,000$, but only after its demands for extra security were met satisfactorily. DJB recognized that the fate of the $\mathrm{KB}$ and possibly of numerous other 'houses' rested on a favourable decision. It was obvious that the downfall of the $\mathrm{KB}$ would create a panic which could trigger a series of bankruptcies. ${ }^{42}$ The loan of $f 200,000$ postponed the inevitable by only a couple of days. Director Hudig of the $\mathrm{KB}$ had calculated that $f 1,500,000$ was needed to cover short-term debt and an additional $f$ 3,000,000 to provide working capital for the agricultural enterprises administered by KB. Given the extremely low prices for sugar and coffee, the current deficit would amount to at least $f 1,000,000$. On 11 November 1884 the KB applied for suspension of payment which was granted on 14 November 1884. By now, the crisis had become full-fledged. ${ }^{43}$

The most striking aspect of the Sugar crisis of 1884 is its omnipresence. It pervaded every corner of the commercial world of Java. This demonstrates the myriad connections between bankers, traders and planters and above all the great interdependence of these connections. Because of this interdependence the 'system' could grow to such proportions and hold out for so long. At the same time it was also the main cause of its spectacular collapse. What constituted the core of this so-called system, was the craving for (working)capital and the endemic shortage of it. An exogenous factor - one that could not be influenced - contributed to its demise. The price fall of key commodities, especially sugar and coffee, signalled the end of a period of transition.

\footnotetext{
41 NA/KB 883: 76.

42 BI/DJB 52 No. 48: 176-18o.

43 NA/KB 883: 76-79.
} 


\section{The Crisis Experienced: Internatio and Dorrepaal \& Co.}

The experience of 1884 will be illustrated by the vicissitudes of Internatio and the trading company Dorrepaal \& Co. Internatio fared relatively well during the crisis and managed to reorganize itself. Dorrepaal \& Co. was one of the most interesting though least known Indies trading firms. The archive of the company seems not to have survived. Fortunately, material regarding this eminent trading firm could be retrieved in secondary sources, because of its standing, huge scale of activities and spectacular downfall in the 1880 .

\section{Internatio}

How did Internatio fare during the upheaval of the mid-188os? The company did not survive its first twenty years' of existence without a scratch. In the two memorial volumes published in commemoration of Internatio's 5oth and 75 th birthday the crisis of 1884 - though decades ago - still figured prominently ([Internatio] 1913: 14-24; [Internatio] 1938: 19-29). The problematic twenty-year period before 1884 was depicted as a learning process which the company had to go through, and in which trial and error were viewed as natural companions. The events of 1884 were considered a turning point for Internatio.

Internatio was first and foremost a general trading-company. In the early years of its existence Internatio was involved in almost every sector of the Netherlands Indies economy (Sipos 1992: 5). It took part in banking, had an interest in agriculture and industrial production and represented different shipping and insurance companies. Trade however came to form the backbone of the company, not least because of the experience of 1884 and its aftermath. Initially, the import of textiles from the Netherlands constituted Internatio's core business in the Netherlands Indies. The founding of the company was driven by textile producers operating from Twente in the east of the Netherlands. But soon the company started to import other products and ventured into the export business. This inevitably led to engagements in agricultural enterprise.

This agricultural involvement can be deduced from Table 3.3. On the even of the crisis Internatio had committed itself for $f$ 7,900,000 and entered into relations with 55 enterprises. These commitments consisted mainly of consignments contracts. From the start Internatio's management had tried to refrain from outright ownership of agricultural enterprises. Internatio's business was conducted as much as possible on the 
basis of consignment. Trading for own account was only done to secure more consignment contracts, following the losses incurred in the first years of its existence. The company's trading activities were not allowed to run any risk since depreciations had to be booked on Internatio's agricultural undertakings time and again. Turnover generated by commission was therefore the most important source of income for Internatio at least until the First World War (Sipos 1992: 13).

This kind of risk-minimizing practice was a common feature in the Netherlands Indies. It has been estimated that before 1914 approximately $95 \%$ of all imports into the colony were consignment shippings and only $5 \%$ was imported by traders for own account. ${ }^{44}$ When a trading company acted as a broker, it was the producer who took the risk of non-payment after delivery. The trader's mediation was naturally rewarded with a commission which was a negotiated percentage of the price. If the producer did not wish, or could not afford to run this kind of risk, he could request the trader to ensure payment of the products after the client had received them. Acceptance of this additional task earned the trader an extra commission. ${ }^{45}$

The fact that producers were willing to accept the conditions of consignment stemmed from certain advantages (Sipos 1992: 10-11). First, it allowed the producer to export to regions of which he had no intimate knowledge. Second, if the intermediary on the spot worked for several producers sales costs could be split and consequently lowered; i.e. cost reduction through management of scale. Third, by closing these contracts the broker received a regular assortment of different goods geared towards a regular clientele which contributed to a levelling of fluctuations in turnover. Fourth, the broker would improve his ability to assess the growth possibilities of interesting markets and the trustworthiness of participants operating there. Last, since sales and the concomitant price level were determined after arrival, import duties could only be levied on the cost price of the shipped goods. This contributed to a better profit margin.

The major disadvantage of this system from the producer's point of view was the fact that he needed to maintain stock both at home and

44 See the article 'Het nieuwe beeld van den Indische importhandel' published in De Indische Gids (IG) 452 (1923) 898-90o. Although not explicitly stated, the author presumably referred to the period 1870-1914.

45 Such commission payments showed up in the financial accounts of trading companies under the heading delcredere (Sipos 1992: 10). 
abroad. This curtailment of cash-flow was exacerbated by the fact that payment upon delivery was not feasible. The resulting time period could be bridged only with the help of (bank) credit (Alting Mees 1884:46). With all this capital tied up - parts of it in places thousands of miles away - he would be anxious to exert some kind of control. Access to good and reliable information was of key importance in this respect and producers would go to great length in achieving this. An example of the efforts companies undertook to safeguard their interests in the colony is provided by the Dutch textile firm H.P. Gelderman \& Zonen just before 1880 (Simons \& Tophoven 1994: 46, 52-53). The frequent and detailed correspondence with textile importers shows how information was obtained, processed and dealt with for the purpose of minimizing risk.

In other words, access to information was an important and necessary precondition for this Dutch enterprise to establish security. A goal achieved by granting only a few import firms in the Netherlands Indies the right to sell the products of H.P. Gelderman \& Zonen on condition that they would refrain from deals with other textile manufacturers. H.P. Gelderman \& Zonen also participated financially in the Surabaya trading company Harmsen, Zorn \& Co. to obtain an exclusive production outlet as well as an important source of information (Fischer, Van Gerwen and Winkelman 1991: 98-112). With their importers not trading textiles of competitors H.P. Gelderman \& Zonen could provide information regarding its products without fearing that someone was eavesdropping.

The establishment of Internatio in 1863 fits this pattern of security enhancement. In this case two textile firms, G. \& H. Salomonson and Van Heek \& Co. opted for active participation in trade. Like H.P. Gelderman \& Zonen both were in search of a more secure outlet for their products in the colony after experiencing disappointing results with other firms for lack of specialized expertise in the textile trade. Internatio indeed started operating as their sole intermediary, primarily on a consignment basis. The broadly defined goals of the company, however, left enough room to take part in the export of agricultural products. This required substantial advances. Internatio rapidly became involved in the financing of agricultural enterprise and eagerly participated in the prevailing credit system.

In 1868, right after the dismissal of C.S. van Heekeren as chief agent, Internatio was committed to 23 enterprises (up from thirteen) for a total amount of $f 620,000$. In 1873 the number of enterprises (22) had not significantly altered, but total capital outlays had more than doubled to $f 1,300,000$. By 1878 spectacular growth had set in and Internatio was committed to no less than sixty enterprises with capital advancements 
reaching $f 3,300,000.46$ DJB started to get worried and in May 1879 Internatio's chief agent, W. Suermondt, was summoned to provide information on the state of affairs. ${ }^{47}$ Suermondt acknowledged that 1878 had been a rather bad year for Internatio. Product sales of the 1877 harvest had not been satisfying and the remaining stock would burden the 1878 balance sheet. The Surabaya agency, unfortunately, had had to write off a loss of $f 110,000$ due to the bankruptcy of various Chinese clients and the other agencies had suffered losses as well. Suermondt assured DJB that these losses were covered by earnings from interest and commission payments. He also emphasized the special reserve of $f_{300,000}$ to prevent a crisis in case of a liquidity shortage. The announcement that Internatio was able to furnish all its agricultural advances out of its own means carried most weight. DJB's Board of Directors accepted Suermondt's explanation since Internatio kept its credit facilities under the same conditions.

Internatio's strength was based on a policy of maintaining a degree of liquidity. Management in Rotterdam, often in conflict with its representatives on Java, kept emphasizing the prudence of financial room for manoeuvre. Tying up all assets in agricultural export produce was deemed irresponsible. In 1867 , the Directors stated:

We have - and will in the future continue to give priority to the repayment of advances which were earlier provided to strengthen initial capital, and were consequently tied up for considerable time. For no matter how small the attached risks, and no matter how significant the stipulated interest and commission on the other hand may be, a trading institution [...] should have a substantial amount of its capital available which is not feasible as long as such significant funds are tied up in agricultural enterprises. ${ }^{48}$

Strict adherence to this sensible line of conduct proved difficult. ${ }^{49}$ Youthful enthusiasm in the newly founded company, the independent position of its agents and a generally optimistic outlook on the future economic prospects of Java resulted in a drive to obtain a portion of the commission trade. The advancement of working capital became endemic. Additional capital often had to be supplied in order to make sure that the planter could at least harvest and deliver the product. This extension of credit - essentially rescue operations - did not go unnoticed, but retreating would incur considerable costs. In its first years of existence, Internatio

\footnotetext{
46 Archive Internatio Doc. 22: 6, 11.

47 BI/DJB 47 Nr. 8: 130-132.

48 Jaarverslag Internatio 1867 (1868) 17.

49 Archive Internatio Doc. 22: 3-12.
} 
was not prepared to start writing off debts on a considerable scale. Instead, it occasionally took over defaulting clients and operated their enterprises themselves in order to save at least a part of the outstanding claims. We should also keep in mind that the Rotterdam management guidelines were not always followed by its representatives on the spot. The means of communication between the Netherlands and Java were poor and the connection between directors and agents quite loose. This put the agents in an independent position and sometimes presented the head office with a fait accompli.

In 1866 Internatio came into possession of the sugar factory 'Ketanen' in Central Java after its owner could no longer meet his obligations. Since no one could be interested Internatio felt obliged to buy it in an attempt to prevent the loss of its claim. At the time it already owned a tobacco plantation and had a 50\% stake in another one. By 1870 these accounts were finally dissolved and off the balance sheet. Management stated:

Although, according to the messages of the chief agent, the accounts of most enterprises mentioned earlier may be considered satisfactory, and consequently these businesses can be regarded a reasonably sure source of fixed revenues, we have not failed to state repeatedly that the operations of the 'Vereeniging' should not be extended in this direction and the sale of the sugar factory and the abolishment of the tobacco-interests will lead to an important improvement in this respect. ${ }^{50}$

In spite of lip-service paid to a cautious policy of operating on the agricultural export market, Internatio's commitment in this field slowly expanded. In 1882 the company advanced money to 73 agricultural enterprises for a total amount of $f 7,300,000$. In addition Internatio had $f 820,000$ invested in companies it operated itself. Given a total capital of $f_{5,000,000}$ and reserves of $f 5^{\circ}, 000$, Internatio's resources were severely stretched. In recognition of this, and encouraged by the coffee leaf disease sweeping through Java, coffee interests were scaled down from 36 in 1882 to 20 in 1884. Nevertheless, during the entire period 1871-1884 management was in two minds about the course to follow. A.C. Mees would write in 1938:

It all looked very fine; but there was a catch, and - seen in the light of later years - it would have been much better to pay out less [i.e. dividend] and ensure a more cautious valuation of many assets and debt accounts of cultural enterprises on the one hand, and generate much more powerful reserves on the other. ${ }^{51}$

50 Jaarverslag Internatio 1870 (1871) 8.

51 See [Internatio] (1938: 18). 
Internatio was hit hard when prices plummeted, although it was able to withstand the storm better than others. Internatio's position in November 1884 showed reasonable prospects. Still, public trust started to dwindle judged by the declining stock market value of Internatio. On 24 April 1884, after paying out a $6 \%$ dividend over 1883 , Internatio's shares reached a quotation of $118 \%$. On 1 July share prices had dropped to $115 \%$, reaching parity on 14 October. This trend was reinforced after the outbreak of the crisis and on 27 November shares had dropped to $80 \%$. On 8 December 1884 shares stood at $68 \%$. The lowest point was reached in 1886 when the share price touched bottom with a quotation of $60 \%$ ([Internatio] 1913: 17). ${ }^{52}$

The public's distrust of Internatio's ability to survive seems unjustified, but it lacked the information to make a correct judgement. Internatio tried to convince those in doubt that there was no threat of a collapse. On 11 November 1884 it published and circulated a leaflet warning against exaggerated concerns. The 'Vereeniging' was financially sound and run with prudence. Regarding its commitments with cultural enterprises the management pointed out that at the end of 1884 total reserves would have risen to $f 1,750,000.53$

On 25 November 1884 agent Suermondt in Batavia received a telegram from Rotterdam informing him of the increasing distrust. He was advised to make sure that the agencies' liquidity was as high as possible. The same day he received another, more optimistic, message which read that he did not have to worry about payments in Europe and that a debenture loan seemed possible. In early December he was reassured that no remittances to Rotterdam were called for, and that he could use all available financial means in the colony itself. Suermondt did not have to take measures. He had $f$ 1,100,00o of liquid assets at disposal, against goods worth $f 475,000$ to be paid upon delivery. ${ }^{54}$ Head office in Rotterdam nonetheless decided that additional capital was urgently needed and went ahead with plans for a debenture loan of $f 2,500,000$. Suermondt told DJB on 8 December that the loan had been successful. Participants included the NHM for $f_{250,000}$, the Rotterdamsche Bank for $f_{200,000}$ and a consortium of four Rotterdam bankers for $f 850,000.55$

\footnotetext{
52 BI/DJB 52 No. 62: 280.

53 See Appendix 5 in [Internatio] (1938).

54 BI/DJB 52 No. 62: 280-281.

55 BI/DJB 52 No. 65: 290.
} 
Internatio now faced the daunting task of removing accumulated bad debt. The choice was between a drastic depreciation that would slash capital outlays, or a slow reorganization that would take years. The latter option was chosen as a result of which complete recovery would take until 1905 ([Internatio] 1913: 17-24; [Internatio] 1938: 26-29; Sipos 1992: 7). ${ }^{56}$ For years Internatio was in a "liquidation process" which absorbed most profits. At the same time a more professional structure was established. Up-to-date information from experts in the field of agriculture and engineering had shown itself to be of great value. Advisors were appointed, cultivation methods were improved and cost prices were brought down. Financial planning and cost management became important tools to guard investments. ${ }^{57}$

Choosing a slow pace of reorganizing had one major disadvantage. In the first years after the crisis, many kept doubting Internatio's stability. 58 In July 1886 the agents of DJB in Semarang and Surabaya were instructed to restrict Internatio's credit to a maximum period of thirty days. An exceptionally short time since normal agreements stipulated expiry dates of 6o-9o days. DJB acted on the basis of the latest annual report of Internatio for the year 1885 which showed a tied-up capital of several million guilders. ${ }^{59} \mathrm{~A}$ credit restriction ordained by DJB could have wideranging repercussions since it curtailed the firm's operating capacities, thereby damaging its reputation and undermining its trustworthiness. A response from Internatio's agent in Batavia was necessary.

When notified of DJB's decision Suermondt tried to refute the basis upon which the decision rested. ${ }^{60}$ In a report he attempted to downplay the extent of Internatio's problems. However, he could only admit to the fact that too much capital was tied up. In his own words:

I totally agree with you [i.e. N.P. van den Berg], that we have much too much capital immobilized in agricultural undertakings; we did not reach this

56 Archive Internatio Doc. 22: 13-14.

57 Ultimately Internatio's agricultural activities would be managed by the Centrale Cultuurafdeling, founded in Semarang in 1920. Many advisors were employed: agricultural and mechanical engineers for the cultivation of sugar and the so-called Bergcultures (cultivations on higher altitudes such as rubber, tea, and coffee), a chemical engineer as well as an administrative and financial consultant (Archive Internatio Doc. 22: 8-9, 13-14, $36-37)$.

58 Its stock market value, as an indicator for the amount of trust people put in Internatio, has already been mentioned. Until 1886 Internatio's shares were not in demand and traded at the stock market for bottom prices.

59 BI/DJB 54 No. $16: 141-143$.

60 BI/DJB 54 No. 24: 178-187. 
point through indifference or ignorance, but through circumstances, which we were not able to change $[\ldots] \cdot{ }^{61}$

According to him, these circumstances came down to bad harvests, the spreading coffee leaf disease which accounted for part of the bad harvest and the unprecedented price fall of sugar. He continued by saying:

It does not help to dwell on this; much more practical is the question, whether people have faith in our policy and energy, our ability to return to a healthy situation, and with respect to this, I believe to be able to point to an improved situation, in which we can take comfort. ${ }^{62}$

However, emphasizing a reduction of total immobilized capital by $f_{508,427}$ did not impress DJB since it amounted to a relative decrease of a mere $5 \%$. Total capital tied up in agricultural enterprises at the end of 1885 stood at $f 9,248,876$. Suffice it to say that DJB did not feel inclined to change its decision. Internatio was in for a rough ride.

Although Internatio scaled down its activities in export agriculture in order to liquidate bad debt, it did not abandon its participation in this economic sector. The number of contracts with agricultural enterprises never dropped below fifty in the years before 19oo. The amount of capital committed to them decreased, albeit at a slow pace. In 1900 total engagements of Internatio in agriculture amounted to $f 4,460,000$. A reduction of capital outlays over a period of fifteen years to only half. ${ }^{63}$ The backbone of the company was in trading, but opportunities in agriculture remained too important to neglect. In the case of the HVA this would ultimately result in a complete focus on agricultural business (i.e. sugar) in 1910. The import and export business was abandoned and Internatio took over many of its clients, profiting especially from the acquisition of a highly developed distribution system. ${ }^{64}$

In 1884 this outcome could hardly have been predicted. Founded in 1879 the HVA was still a small player in the field. As noted the HVA had contacts with seven agricultural enterprises. Total commitments comprised $f$ 1,150,00o which was quite unimpressive when compared to others (see Table 3.3). The HVA did not suffer immediate losses due to the crisis. In December 1884 its agent Benjamin even requested a loan from DJB to furnish working capital for three sugar factories. ${ }^{65}$ According to him these

\footnotetext{
61 Ibidem, 181.

62 Ibidem.

63 Archive Internatio Doc. 22: 17.

64 See Chapter 5, Paragraph 'The HVA and Agricultural Enterprise'.

65 BI/DJB 52 No. 66: 293-294.
} 
Table 3.3. Financial institutions and agricultural enterprises, 1884.

\begin{tabular}{lrrrrrr}
\hline & \multicolumn{3}{c}{ Enterprises } & & Engagements \\
\cline { 2 - 4 } & sugar & coffee & others & total & $(f)$ \\
\hline Dorrepaal \& Co. & 22 & 38 & 53 & 113 & $13,125,000$ \\
HVA & 4 & 2 & 1 & 7 & $1,150,000$ \\
Internatio & 12 & 20 & 23 & 55 & $7,900,000$ \\
Koloniale Bank & 9 & 17 & 12 & 38 & $7,700,000$ \\
NHM & 30 & 12 & 5 & 47 & $6,900,000$ \\
NIHB & 29 & 20 & 4 & 53 & $22,500,000$ \\
\hline
\end{tabular}

Sources: Archive Internatio Doc. 22: 11; BI/DJB 52 No. 92: 483-516; BI/DJB 54 No. 24: 182; Furnivall (1939: 197); Helfferich (1914: 39, 140-141).

factories were excellent, working cheaply and completely free of debt. He would very much like to include them among his clients, but lacked sufficient funds. A strange request, considering the fact that as late as 27 December 1884 the agent of the KB would write to his management:

Importers are not selling anything, are not receiving any money; machine factories are not getting any orders; employees of factories are being dismissed, etc. Banks are not discounting paper [i.e. bills of exchange] from importers anymore. ${ }^{66}$

N.P. van den Berg, after hearing Benjamin, did not even bother to consult the other Directors but refused his request downright, adding that this was not the time to invest capital in agriculture and that they needed their funds to support their import business. He was proven right. In May 1885 the HVA had to write out a debenture loan of $f 1,500,000$. Eventually, the money was raised but only with difficulty (Helfferich 1914: 123). ${ }^{67}$

\section{Dorrepaal \& Co.}

At the onset of the crisis Dorrepaal \& Co. conducted business with 113 companies. The company's total outstanding credit amounted to $f_{13,125,000}$ (See Table 3.3). Among its clientele were 22 sugar factories and 38 coffee plantations. Dorrepaal \& Co's fortunes were highly correlated with a continuation of the bull market for agricultural export products. After the market collapse of 1884 Dorrepaal \& Co. put up a desperate fight

\footnotetext{
66 NA/KB 883: 71.

67 NA/KB 883: 97.
} 
for survival to no avail. After a prolonged battle one of the most renowned trading companies in Java disappeared from the scene. Its strongly personalized structure, seemingly well-suited to survive any kind of strain, proved outdated and necessitated a restart in a different and greatly reduced format. Its founder, G.L. Dorrepaal, would never know about the collapse of his life's work. He died shortly before the outbreak of the crisis.

On 4 May 1883 Georgius Leonardus Dorrepaal passed away in The Hague, where he had retired after living for many decades in Java. Born in 1816 in the Netherlands, he arrived in the colony in 1840 and settled in Semarang. He associated himself with A.E. Soesman who had started his own trading business in $1835{ }^{68}$ From approximately $1841 / 42$ onwards Soesman \& Dorrepaal provided working capital to agricultural enterprises located mainly in the Principalities (De Bree 1928-1930: II 412). ${ }^{69}$ Around 1843 Dorrepaal established his own company under the name Dorrepaal \& Co. ${ }^{70}$ One year later he married Ludovica Manuel (1817-1896) daughter of the deceased owner of 'Peterongan', a huge private estate near Semarang. How he financed his business activities remains unclear. He might have received Chinese financial support, either from Chinese moneylenders in Semarang, or possibly through the mediation of his brother-in-law C.H. Manuel who lived on 'Peterongan' together with a Chinese woman (Bosma and Raben 2003: 122-124).

Little is known about the early activities of Dorrepaal \& Co. Until 1850 the company remained quite small and was certainly not counted among the big and influential names in the trading business in Semarang. The firm was active in import and export on a rather humble scale. In the years before $185^{0}$, Dorrepaal and Co. registered as exporter only once. ${ }^{71}$ Between $185^{1}$ and 1863 , it chartered nine ships for the export of goods to the Netherlands. The import share of the company's business seems to have been considerably less. During the same period only one ship was chartered to bring in goods from the Netherlands. ${ }^{72}$ This is no surprise, considering the later development of Dorrepaal \& Co. and its early commitment

\footnotetext{
68 See Appendix 1 in Mansvelt (1938).

69 NA/KB 883: 94.

70 Ibidem.

${ }^{71}$ See Appendix 3 in Mansvelt (1938). Up till then, it was common practice to charter a ship for its complete tonnage. The names of the companies that commissioned those ships showed up in the trade statistics. When export traders started to charter ships for joint account, the possibility of identifying the respective participants gradually disappeared. Single companies kept chartering ships, but these data do not give a complete picture of their trading activities (Mansvelt 1938: 8-9).

72 See Appendices 2 and 3 in Mansvelt (1938).
} 
to agricultural enterprises primarily geared to export. The company slowly consolidated its position and concentrated on the abundant business opportunities in Central Java (including the Principalities).${ }^{73}$ It improved its standing and reputation considerably and its wishes and needs were increasingly noted. Early 186 os Dorrepaal \& Co. had 'arrived'. Less than a decade later, G.L. Dorrepaal's position among planters and traders was absolutely unrivalled; he had become the undisputed 'king' of Central Java. ${ }^{74}$

In the 1870 s some important changes occurred. After approximately forty years in the trading business G.L. Dorrepaal decided to withdraw in favour of C.L. Dankmeyer and his son-in-law W.L. Mirandolle. However, his stake in the company was still by far the greatest. ${ }^{75}$ In 1878 the firm's total capital amounted to $f 2,540,000$ furnished by seven partners. G.L. Dorrepaal's share was $f 1,500,000$ or $60 \%$ of the company. This was a sizeable share which turned out to be even larger, since he had furnished short-term credit of $f 1,000,000$ to be repaid in monthly instalments over the next eight years. Dankmeyer, with a share of $f 350,000$ the second biggest participant, must have been buoyant in his expectations for the future. After all, the company stood at the height of its power. Its position was acknowledged and it wielded considerable influence. ${ }^{76}$ Business was running smoothly and was well founded in a sound financial situation with enough room for further development. The general economic outlook was excellent and the company was well prepared to take advantage of this.

Dankmeyer, the company's spokesman, therefore requested DJB in September 1878 to consider establishing a new agency in Yogyakarta. ${ }^{77}$ The desirability of an agency in the Principalities (Yogyakarta and Solo/ Surakarta) was demonstrated by presenting DJB-President Van den Berg an overview of Dorrepaal \& Co's substantial engagements within the Yogyakarta residency. Van den Berg, present in Semarang for a routine inspection of the Java agencies, listened carefully. In 1867 agencies had already been established in Solo and Pasuruan (De Bree 1928-1930: II 579),

\footnotetext{
73 BI/DJB 39 No. 78: 72-76.

74 For more details on Dorrepaal's status in colonial society, see Bosma and Raben (2003: 125-126).

75 BI/DJB 46 No. 39: 371.

76 For example, G.L. Dorrepaal was a commissioner of the Semarang agency of DJB for many years and when in 1879 DJB's new statute was drafted, a representative of Dorrepaal \& Co. acted as a consultant.

77 BI/DJB 46 No. 78: 371-372.
} 
but there might be sufficient reason to review the situation. Upon Dankmeyer's and other people's information Van den Berg decided to extend his visit and travelled through East and Central Java to see for himself. In his final report he wrote that the situation in the Yogyakarta area could be characterized as exceptionally good and that in his view an agency would be of great value (De Bree 1928-1930: II 184). We will never know if the financial needs of Dorrepaal \& Co. tipped the balance in favour of a new agency, but the outcome was positive. The decision to establish an agency in Yogyakarta was taken surprisingly fast and on 1 April 1879 DJB opened the doors of its newest agency.

Dorrepaal \& Co. seemed to be doing excellent, but concerns were suddenly raised about its financial situation. In December 1878 DJB's Board of Directors contemplated their commitments in Central Java and decided that no more credit should be extended to companies (partially) owned by Dorrepaal \& Co. unless the firm was willing to accept short-term bank credits with a maximum of ten days. ${ }^{78}$ The agent in Semarang was urged to visit Dorrepaal \& Co. and ask to see the books in order to allow a better assessment of its commitments. Evidently, DJB feared an overextension of Dorrepaal \& Co's financial strength. However, in September Dankmeyer's answer to Van den Berg's inquiry regarding the financial situation of Dorrepaal \& Co. was accepted.

This sudden reversal of attitude towards a well-respected and longtime client was caused by two reasons. First, as we have seen, the end of 1878 saw a crisis within DJB between Directors and Commissioners which steered the bank into a more conservative course (De Bree 1928-1930: II 196-203, 207-220, 224, 228). Second, at the end of November 1878 the agent in Semarang had compiled a list of clients operating in the Principalities. ${ }^{79}$ This list must have been extremely alarming. It showed 39 enterprises engaged in agricultural activities (predominantly sugar and coffee, to a lesser extent tobacco and indigo) with the names of their owners, administrators and financial backers. The name of Dorrepaal as financial backer and/or owner appeared 32 times on this list. The Directors worried: how sound were all these commitments? What if Dorrepaal ran into trouble? With such an influential position in the all-important Javanese heartland, the company's default could assume catastrophic proportions.

78 BI/DJB 46 No. 57: 658-659.

79 BI/DJB 46 No. 57: $665-672$. 
The reply from the Semarang agency came two months later and was partly reassuring. Dorrepaal \& Co. had fully co-operated in allowing access to its books and the resulting report satisfied the management in Batavia. They had to admit that with business on such a scale the requested and already extended credit was quite moderate. Therefore, a modest expansion of outstanding loans was permissible. However, the negative outcome of the conflict with the Commissioners made the Directors cautious, and the decision was made not to deviate from the earlier reduction of credit facilities. ${ }^{80}$

According to the earlier mentioned list Dorrepaal \& Co's activities spread out from its Semarang base in the direction of the Principalities. ${ }^{81}$ With Central Java as its main operating field, its scale of business was large. In the eyes of DJB this was alarming, partly because its Semarang agency had come to rely too much on the Dorrepaal \& Co. account, and partly because Dorrepaal \& Co. could be indebted to other banks as well. This would make its scale of business even bigger, but also more complex and ambiguous. A disturbingly large number of enterprises were connected to each other and to Dorrepaal \& Co. Dorrepaal \& Co. would act as financial backer, as owner, or both at the same time. In many instances Dorrepaal \& Co. had advanced money to enterprises partially owned by G.L. Dorrepaal himself. The same G.L. Dorrepaal who still owned $60 \%$ of the company and had provided an additional loan of $f_{1,000,000}$.

As long as there was no interruption in the company's cash-flow, business continued to run smoothly. Although DJB's sudden credit restriction caused some concern, it could be dealt with because market conditions remained favourable. Dorrepaal \& Co's reputation was solid. This Semarang trading company served, in the eyes of many, as a good example of daring entrepreneurial behaviour.

In the eyes of the KB Dorrepaal \& Co. also constituted an ideal business partner, whose network of clients and contacts were welcomed to support the KB's fledgling business operations. The KB even contemplated taking over Dorrepaal \& Co's business. In 1881 talks were held in Amsterdam with the old patriarch, G.L. Dorrepaal, and an associate of the company, J.H. de Kanter. In September 1881, however, Hudig figured a take-over would probably not succeed. A major obstacle was the company's ownership of planatations. By statute the KB could not possess agricultural enterprises. Splitting up Dorrepaal \& Co.'s business interests

80 BI/DJB 46 No. 76: 815.

81 BI/DJB 39 No. 76: 62-68. 
seemed a way out, but the option was rejected outright by the associates of Dorrepaal \& Co. G.L. Dorrepaal himself was at any rate opposed, since a take-over by the $\mathrm{KB}$ would mean losing the name Dorrepaal which he found unacceptable. In the end the negotiations faltered. A business relationship was nevertheless established soon afterwards. At the end of February 1882 the KB agreed to a one-year loan of $f$ 300,000 which was repeatedly prolonged. ${ }^{82}$

On 30 January 1882 the position of Dorrepaal \& Co. was once more under critical review by DJB. ${ }^{83}$ The immediate cause was Mirandolle's request for an additional credit of $f_{300,000}$. DJB had extended this credit for the last three years, although it was considered a temporary measure in order to alleviate minor payment difficulties. Mirandolle's letter to Director A.A. Buijskes was not well received. Acting President Buijskes argued against prolongation of the loan. His reasoning gives a rare insight into the root causes of Dorrepaal \& Co.'s accumulating problems acknowledged almost two years before the actual demise of the company.

Buijskes identified a number of problems which would take several years to sort out. First, there was the principal consideration of not using a short-term loan for long-term purposes. Approving the same credit for the fourth time would be tantamount to a continuous credit. Second, if guaranteed sufficiently this did not have to be problematic, but determining the solidity of guarantors remained troublesome. In the case of Dorrepaal \& Co. the second consideration was of greater importance. According to Buijskes, the sheer volume of the company's business combined with its diversity complicated matters considerably. In addition, he expressed an acute awareness of:

[...] the extreme difficulty - indeed - sheer impossibility of acquiring accurate knowledge of the relations between planter and money lender. ${ }^{84}$

Buijskes continued by saying that most of the credit extended by Dorrepaal \& Co. was not guaranteed at all and in the case of difficulties would come to bear on the company itself. In other words, there was no safety net. Dorrepaal \& Co. had large resources at its disposal, but in case of a calamity it would take months, if not years, to straighten things out. Buijskes' third consideration touched upon the problem of credibility. He claimed that the company's credibility originated from the founder's personal

\footnotetext{
82 NA/KB 883: 31-32.

83 BI/DJB 49 No. 49: 330-333.

84 Ibidem: 331.
} 
fortune, and he was of an advanced age. G.L. Dorrepaal could pass away in the foreseeable future, leaving the company without his influence, reputation and money.

Buijskes concluded by pointing out that Dorrepaal \& Co. was committed to more than 90 enterprises. These commitments did not consist of uniform contracts. Instead, a bewildering variety of arrangements (debentures, bills of exchange, promissory notes, etc.) had been concluded. In Buijskes words:

[...] something that - in case of a possible disruption of the regular state of affairs - will give rise to such a chaos of complications, that it will not be possible to work out what will come of it $[\ldots . .]^{85}$

He therefore strongly urged discontinuing Dorrepaal \& Co's credit. With President Van den Berg not present at the time the decision was postponed until further notice.

It would take a month before the matter was taken up again. On 24 February 1882 N.P. van den Berg addressed the issue of Dorrepaal \& Co at the weekly meeting of DJB's Board of Directors. ${ }^{86}$ Although partly agreeing with Buijskes, he did not share all of his objections. Above all, he found it implausible that the general public would react extremely to G.L. Dorrepaal's death. No such thing had happened when G.L. Dorrepaal resigned in the late 1870 os which offered enough reassurance. Besides, provisions had been made to prevent G.L. Dorrepaal's capital from being withdrawn upon his death. This capital would have to stay in the company another eight years, contributing to the stability of Dorrepaal \& Co. Buijskes' reaction was one of caution. The general public, far less familiar with the histoire intime of the company, would surely adjust its opinion concerning the reliability of Dorrepaal \& Co. upon hearing of the death of its founder. As far as he could tell, G.L. Dorrepaal was still highly regarded by the public.

D. Groeneveld - like Buijskes a member of the Board of Directors opined that Dorrepaal \& Co's account with DJB had amounted to $f 800,000$ over the last few years. Including the extraordinary loan the account had more than once risen to $f 1,200,000$. A "colossal amount" according to him that he would not like to see in the books again. Nevertheless, he favoured accommodating Dorrepaal \& Co. with the required $f 300,000$ provided that such a request would not be granted again in the future. After this

\footnotetext{
85 Ibidem.

86 BI/DJB 49 No. 53: 351-353.
} 
was decided DJB's agent in Semarang was authorized to extend credit up to $f 200,000$ immediately.

N.P. van den Berg's favourable standpoint regarding credit extension for trading and agricultural purposes might be contributed to his past working environment. Before accepting the position of President of DJB in 1873, he had been the Chief Agent of the NIHB in Batavia from 1864 onwards. His first hand knowledge with regard to the (financial) needs of private enterprise derived from this position. We can probably date his first encounter with agricultural enterprise as early as 1864. Van den Berg's brother-in-law was Karel Frederik Holle, a famous entrepreneur in the history of the Netherlands Indies. He was a man of many talents. Holle was active as a scholar, educator, admirer of the Sundanese culture, active promoter of new agricultural methods and poetry. He also became famous as a tea planter with his own plantation 'Waspada'. He had been the administrator of another tea plantation 'Tjikarang' since 1858 and achieved fine results with new cultivation methods. However, like everyone else, he needed working capital (Van den Berge 1998).

For this he turned to N.P. van den Berg, who was not only his brother-in-law, but also a good friend (Van den Berge 1998: 30-32). The two men had a close personal relationship and Van den Berg described Holle in one of his letters as one of the noblest men he had ever met. Van den Berg supported Holle's request for an advance wholeheartedly and tried to convince the NIHB of the soundness of his and Holle's plans. Management in Amsterdam was hesitant and sent Van den Berg a letter on 7 June 1864 warning him not to let his judgement be influenced too much by feelings of friendship. Van den Berg persisted and emphasized the increased competition of the NHM. In December 1864 the loan was approved and the consignment contract was signed on 4 January 1865 . Holle was in business.

Van den Berg soon found out that the policy of the NIHB had not essentially changed. Its Directors remained reluctant to advance money to agricultural enterprise and were not prepared to sign any more consignment contracts (Korthals Altes 2004: 91; Van Zwet 2004: 114). The risks were considered too great and the rewards too small. Van den Berg's next job at DJB gave him more opportunities to support private enterprise, although DJB was severely restricted in this field of operations. ${ }^{87}$ Short-term credit, for the benefit of trade only, with sound and tightly guarded security was the

87 See the earlier described conflict between Directors and Commissioners of DJB in 1878-1879 on the matter of extending loans to agricultural enterprises. 
norm. As seen, exceptions could not be avoided. With Dorrepaal \& Co.'s agricultural interests becoming more important, the security it offered became increasingly linked to these same interests. Strict compliance to DJB's statutes would have forestalled such loans, but management closed its eyes and bent the rules somewhat. Van den Berg played an important role here. During his years as President of DJB he was undisputedly in control, although President and Directors got along quite well, and were generally of the same opinion. Disagreements hardly ever occurred. The discussion regarding the extra credit for Dorrepaal \& Co. was unparalleled.

In the few years before the eruption of the crisis, Dorrepaal \& Co. went about their business as usual. The company did not have to ask for additional funds. Business, however, was conducted on an ever larger scale and the agricultural commitments became vast. Though described as a general import-export firm, Dorrepaal \& Co. had become the largest financier of agricultural enterprise in the colony. Its import business had withered away completely and both in absolute and relative terms amounted to almost nothing. ${ }^{88}$ At the end of 1884 a financial survey of Dorrepaal \& Co showed imported goods worth a total of $f 850,000$. This total included $f 300,000$ worth of goods imported on behalf of the company Van der Linde \& Teves. Dorrepaal \& Co. - personified by A. Mirandolle - was an associate in this Semarang-based firm. At the time of the crisis of 1884 it had invested $f 10,000$ in the company and was entitled to $25 \%$ of its profits. Dorrepaal \& Co. had co-founded it on 28 April 1881 in order to provide machinery, materials and other necessities to its many clients in agricultural enterprise. ${ }^{89}$ A large and quite expensive stock was maintained at all times to that effect. Another $f_{28,000}$ was spent to import gunny bags for the transport of agricultural products. In other words, almost $40 \%$ of total imports was directly related to Dorrepaal \& Co.'s agricultural commitments, leaving a mere $f 522,000$ for the import of other goods (e.g. butter). This was a negligible $3 \%$ of total assets, which were conservatively estimated at $f_{17,200,000}$.

88 BI/DJB 52 No. 92: 488, 497, 509.

89 J.A. van der Linde - who started out in Semarang in 1860 - and J.C. Teves had become partners in 1875 and traded primarily in ironware and utilities for factories and agricultural enterprises. They also traded in general import products, but most of this business was soon abandoned. Upon Van der Linde's death in 1880 the company was restructured the following year. Dorrepaal \& Co. furnished part of the starting capital whereupon A. Mirandolle acted as a 'silent partner' (Gedenkboek Lindeteves -Stokvis 1939: 1-2; Kind 2000: 11-12). 
Dorrepaal \& Co.'s agricultural undertakings were of a completely different order. Close study of its balance sheet, made up on 31 December 1882, clearly shows the magnitude of this involvement. ${ }^{90}$ Dorrepaal \& Co. had advanced more than $f 12,500,000$ of working capital to sugar, coffee, tobacco and indigo enterprises. Of these four products the share of sugar and coffee came close to $90 \%$ giving the company an extremely high exposure to world market prices. Total commitment in agriculture exceeded $f 16,100,000$ which was financed in an unorthodox way. The money advanced was guaranteed by, first of all, the different kinds of security planters had offered, like promissory notes and bills of exchange. Second, there was the finished produce that - partly stored, partly shipped - could be used as collateral for cash. This did not cover the obligations completely since it provided a little less than $f 10,000,000$ in liquid assets. This amount was supplemented with $f_{3,700,000}$ of the company's own capital, i.e. shareholder capital and the private accounts of the associates. This still left a gap of more than $f 2,400,000$ which Dorrepaal \& Co. closed by using $f$ 2,610,00o of deposits at its disposal. A highly unorthodox and risky solution since this source of liquid assets could be withdrawn at a moment's notice. As long as the company's profile still inspired confidence, withdrawal on such a scale could be prevented. But maintaining trustworthiness is subject to outside influences and cannot be determined solely by the company itself.

The people in charge of Dorrepaal \& Co - Dorrepaal and De Kanter in Amsterdam and Dankmeyer and Mirandolle in Semarang - knew the inherent dangers. In 1881 ( $f$ 979,00o), 1882 ( $f$ 841,00o), and 1883 ( $f$ 192,000) all surplus profits were used to write off debts, or reserved to cushion unexpected misfortune..$^{91}$ Considering the whole financial picture, these amounts were small. Besides, Dorrepaal \& Co.'s commitments increased in this period. In 1883 and 1884 the company had to take over 4 indigo and coffee enterprises as part of a debt settlement which surfaced on its balance sheet for $f 755,000 .{ }^{92}$ At the same time the profitability of many agricultural enterprises suffered from the strategy of expansion preceding the crisis of $1884 .{ }^{93}$ Investing in new machinery (e.g. steam ploughs), buying land and bringing it into cultivation, constructing new water works,

90 NA/NHM 7939. Around this time Dorrepaal \& Co. financed approximately $45 \%$ of the total sugar production in the Principalities (Bosma and Raben 2003: 251).

91 BI/DJB 52 No. 92: 496.

92 Three of the four enterprises belonged to C.H. Manuel, brother of G.L. Dorrepaal's widow Ludovica Manuel (BI/DJB $5^{2}$ No. 92: 490; NA/KB 883: 94).

93 BI/DJB 52 No. 92: 489, 491-494. 
building and/or modernizing factories were all extremely expensive which put a heavy burden on the whole sector. Though aware of the overheated economy, Dorrepaal \& Co. did not realize how acute the situation really was.

They were not the only ones. Even DJB, who always advocated caution and common sense, was not worried when viewing the information from Dorrepaal \& Co. concerning $1883 .{ }^{94}$ The company's commitments were covered by the estimated value of the received products. It should be remembered that the yield from any harvest was usually sold over a protracted period of time. When prices were not to the liking of the trader, he would - if he could afford to - sit on it and sell it later. DJB must have known that sales had not been realized yet, or at least had not been realized completely. Nevertheless, President and Directors concluded that Dorrepaal \& Co. had performed well during the past year. All this was discussed and decided on 5 May 1884 , when prices had begun to slide and the market seemed shaky. If prices collapsed, expenses could no longer be covered by sales, whereas the company's own assets (shareholder capital + the associates' private accounts) accounted for only $30-40 \%$ of capital outlays in agricultural enterprise alone.

Dorrepaal \& Co.'s high profile instilled confidence until the end. It kept its image of trustworthiness and reliability. In September 1884 the NIHB faced an acute shortage of liquid assets and applied for help at the office of DJB. It was given a short-term credit of $f 600,000$. Interestingly, the required security consisted of coffee $(f 400,000)$ and a credit guarantee $(f$ 200,00o) with the signature of Dorrepaal \& Co (De Bree 1928-1930: II 235).

Apparently Dorrepaal's name was still considered good enough to be accepted as a guarantor for $f \mathbf{2 0 0 , 0 0 0}$ in case of default. This continued to be the case until the end of November that same year. On 20 November 1884 De Kanter telegraphed Mirandolle in Batavia to inform him of a possible suspension of payment. ${ }^{95}$ Mirandolle immediately notified the agent - Dunlop - in Batavia, who informed Van den Berg. At the office of DJB this message was received like a bolt of lightning. No one had expected anything of the kind. Mirandolle's telegram to Dunlop read as followed:

De Kanter signals me our friends have drawn the Government's attention [in Holland] to the great political repercussions, if we have to suspend

94 BI/DJB 52 No. 6: 30 .

95 Dankmeyer had died in March 1884, leaving Mirandolle in charge of operations. 
especially considering that so many enterprises in Solo and Djocja would be temporarily unable to pay rent and activities would cease with the result that a mass of people would be without earnings; he also advises that this be pointed out to the Indies Government, talk to Mr. van den Berg about this. ${ }^{96}$

Van den Berg was stunned when reading this. Only the day before, the 'Factorij' (NHM's head office in Batavia) had given the "most reassuring messages" concerning Dorrepaal \& Co. ${ }^{97}$ The fact that associates in Amsterdam had already called in "friends" to put pressure on the government in The Hague was a bad sign. On 21 November he telegraphed Mirandolle in Semarang:

Dunlop showed me your private telegram of yesterday. As you intended the Governor-General was warned with the utmost seriousness and emphasis of the great political importance of the current situation, yet I doubt very much if our propositions will be accepted. It is even said that the Minister has declared himself by telegram against lending any government support. I will undertake whatever is necessary to promote other views. In the mean time your telegram has alarmed me greatly: I thought matters were handled satisfactorily. Keep me informed: this is desirable in both our interest. ${ }^{98}$

From now on, events happened in quick succession. Mirandolle's answer to Van den Berg's telegram tells us that the most pressing problem for Dorrepaal \& Co. concerned the acquisition of sufficient working capital until the next harvest could be brought to the market. ${ }^{99}$ Trading agricultural produce was a seasonal business as Dorrepaal \& Co.'s estimated budget for 1885 shows. Total expenses for the first six months amounted to $f 6,153,000$. Only $f 4,370,000$ was expected to come in, leaving a deficit of $f 1,783,000$. The second half of the year showed the reversed situation with abundant harvest sales. Total expenses were estimated at $f_{5,940,000 \text {, but }}$ revenue was conservatively judged to be $f 7,500,000$. This created a surplus of at least $f 1,560,000$, nearly balancing the total over the whole year. And these sales revenues were based upon prices standing at an all-time low; sugar in this budget was priced at $f 8$ per picol. ${ }^{100}$

The fluctuation in revenue and expenses required financial help. But, because of the price fall no planter's signature was acceptable anymore and therefore Dorrepaal \& Co had to cough up the money itself which led

\footnotetext{
96 BI/DJB 52 No. 54: 234.

97 Ibidem: 229 .

98 Ibidem: 235 .

99 BI/DJB 52 No. 55: 236.

100 BI/DJB 52 No. 92 Appendix 1-2: 499-501.
} 
to a lack of cash. ${ }^{101}$ The company's assets became tied up amazingly fast. On average, the company had to pay out $f 8,000$ a day ( $f 240,000$ a month) consisting of working-capital for planters, wages, and a diverse range of other expenses. An extra $f_{150,000}$ had to be added for the monthly costs of transport. All this, without counting the payments due on the expiry dates of the many short-term credit facilities which the company used to finance, among others, the expenses just mentioned. ${ }^{102}$

No harm would have been done if the company's nominal capital had been sufficient. However, as shown the company's own means were outstripped about three times by its agricultural commitments alone, a situation which originated from the buoyant economic circumstances of the last few years. With the company's own capital plus short-term deposits now completely tied up, and no chance of further credit, the whole venture came to a creaking halt. ${ }^{103}$

The colonial government was called to the rescue, but stuck to its newly-found principles of laissez-faire. There was formidable pressure to do otherwise and N.P. van den Berg was among the staunchest supporters of government intervention (De Bree 1928-1930: II 237-242, 244-248; Van Zwet 2004: 168-171). Together with Lohr of the NHM and Van Delden of the NIHB (both on the Board of Commissioners of DJB) he presented a memorandum to Governor-General Van Rees on 13 November. ${ }^{104}$ It contained an overview of the crisis and showed a possible way out. Essentially, the key to the problem was a lack of trust in a profitable return of investment. Risk reduction was therefore urgently required. Van den Berg concluded that the legal opportunities of ceding security ought to be broadened. So far, only harvested produce could serve as security, but what about the crops in the field? If these could be pledged as well, it would leave the planters some room to manoeuvre and reduce risks for potential creditors. ${ }^{105}$

Although the government was not willing to spend one guilder itself, this idea was welcomed. Van Rees put his weight behind this proposition which speeded up the bureaucratic procedures. On 26 November Van den Berg was summoned at the Governor-General's office to advise on the problems pertaining to Dorrepaal \& Co. Again he stressed his earlier

101 BI/DJB 52 No. 54: 229.

102 BI/DJB 52 No. 92 Appendix 1-2: 499-501.

103 Ibidem: 484 .

104 BI/DJB 52 No. 51: 207-210.

105 BI/DJB 52 No. 50: 199-203; BI/DJB 52 No. 51: 204-206. 
idea, but added that the NHM was the only one in a position to help out in the Principalities. The government could support the NHM's efforts by giving it the right to dispose of the $f 5,000$,ooo the company had been obliged to deposit at DNB as a security for its government consignments. On 4 December a new law regarding the possibility of ceding field crops was promulgated. Although the planter lost some of his independence when receiving advances under these conditions, he was assured of a more steady credit supply.

In the meantime, it had become obvious that Dorrepaal \& Co. needed to be reconstructed (De Bree 1928-1930: II 247, 249-250). ${ }^{106}$ Debts had skyrocketed. The private fortunes of the associates and their family members simply did not suffice. Early December 1884 the decision was taken to convert Dorrepaal \& Co. into the Dorrepaalsche Bank der Vorstenlanden ${ }^{107}$ with a nominal capital of $f 5,500,000$. Associates and family would do their best to raise this amount up to $f 6,000,000$. At the same time a debenture loan of $f_{7,000,000}$ was issued. Van den Berg was requested to encourage creditors in the colony to participate in this loan as much as possible. ${ }^{108}$ In other words, creditors were asked to agree to a postponement of payment. If agreed upon their deposits would be transformed into debentures, to be repaid over a number of years. Ultimately, $80 \%$ of the debentures were taken. Short-term deposit holders had, however, massively resisted forsaking rapid repayment. Over $f 1,500,000$ had to be paid out upon the original expiry dates. Only in Batavia a mere $f 65,000$ had been converted into debentures. ${ }^{109}$

The share, debenture and deposit holders provide a wonderful image of interlocking relationships in the trading and financial world of Java in this period. ${ }^{110}$ They were all there: bankers, traders, and planters. All the grand family names such as Arnold, Raaff, Pijnacker Hordijk, d'Abo, etc. Only two Chinese names were listed, but these two count. None other than Ho Yam Loo (an important Semarang revenue farmer) and Oey Tjie Sien (the father of Oei Tiong Ham, who founded the huge commercial empire Kian Gwan) felt obligated to invest in the restructured company. The financial sector was equally well represented. Dorrepaal \& Co. had

\footnotetext{
106 BI/DJB $5^{2}$ No. 63: 286; BI/DJB 52 No. 92: 485 .

107 On 18 August 1885 the Dorrepaalsche Bank der Vorstenlanden was founded retroactively as of 17 December 1884 .

108 The Koloniale Bank (KB) agreed, because Dorrepaal \& Co. had participated in its own debenture loan for $f 644,000$. If Dorrepaal should fall, this participation would become worthless.

109 BI/DJB 52 No. 92 Appendix 1, 9-10: 499-500, 572-575.

110 Ibidem.
} 
financial arrangements with all the major banks operating in the colony at the time, i.e. DJB, KB, NHM, NIHB, NIEM, the Chartered Bank, and the Mercantile Bank. Mention should also be made of the Semarangsche Spaarbank, and different insurance companies like the Bataviasche Zee \& Brand Assurantie Maatschappij, the Semarangsche Zee \& Brand Assurantie Maatschappij and the Assurantie Maatschappij 'de Merapi'. Last, Dorrepaal \& Co. had been in contact with a number of trading companies, among others: Kreglinger \& Co., Lens \& Bergsma, and John Peet \& Co. ${ }^{111}$

The debenture loan had not been entirely unsuccessful. The money raised was considerable. The problem was that only $f 1,500,000$ of the available $f 5,760$,ooo could be used. The remainder had to be reserved to settle outstanding debt for which expiry dates were not far ahead. Help from the outside remained necessary. ${ }^{112}$ DJB and the NHM were addressed and it was decided to investigate the company's books. This task was given to the NHM and on 24 December 1884 a member of the Factorij, Fokker, went to Semarang. DJB decided to request assistance from the government once again, since:

[...] the only thing left to consider, is to what extent an attempt can be made once more to make an appeal for Government cooperation in preventing a calamity that could have the most disastrous consequences for Central Java, not just with regard to the law and order of the country, but also with regard to the whole of the import trade, because with the suspension of countless enterprises, who were until now assisted with funds by Dorrepaal \& Co., the money the 'second hand' traders need to honour their obligations to the importers will fail to materialize, and from this can arise a general failure of the 'Chinese quarter' in Semarang. ${ }^{113}$

As expected, the government did not give in and other possibilities had to be considered. One was to tackle the high transport costs of the harvested

111 The NHM-archive contains a somewhat shorter list of important relations showing corresponding names (NA/NHM 2433 No. 391).

112 Throughout the crisis of 1884 DJB and NHM were consistently called to the rescue. More or less pressured by public opinion as well as government circles, both institutions responded admirably to the challenge (De Bree 1928-1930: II 232-271; Van den Berg 1907: 140-142; Mansvelt 1924: II 416-418). Van den Berg even resorted to 'illegal' measures by extending loans against mortgaged capital which directly contravened DJB's statutes. In his unpublished memoirs he would later write: "[...] I have taken personal responsibility for some extraordinary measures, that would undoubtedly have cost me my position in case things had gone wrong." Van den Berg's efforts were greatly appreciated and made him honorary member of several agricultural associations, such as the Japarasche Vereeniging van Suikerfabrikanten (1885) and the Soekaboemische Landbouwvereeniging (1887) (Van Zwet 2004: 169, 191).

113 BI/DJB 52 No. 74: 366. 
produce from the field to the ports of shipment. Transport was done by rail. In order to lower the freight charges of the railroad companies, these firms were petitioned as well. The freight rate had been a source of complaint, but was now becoming a real burden with cost price exceeding the selling price. This burden is exemplified by Fokker's estimation of Dorrepaal \& Co.'s freight charges for the second half of 1885 which amounted to $f$ 90o,ooo. When the Nederlandsch-Indische Spoorwegmaatschappij (NIS) decided to lower its rate for sugar transports in 1885 , he wrote in his report to expect a reduction of transport costs of $f 200,000$ to $f_{300,000 .}{ }^{114}$

On 28 December 1884 it became known that through the combined forces of the Amsterdam financial elite additional capital $(f 2,000,000)$ had been obtained. This persuaded Fokker to advise positively regarding an extra credit of $f 1,000,000$ to $f 1,500,000$. In the end the NHM negotiated a take-over of the consignment business of Dorrepaal \& Co. and advanced $f_{2,000,000}$ on 400,000 picols of sugar. In other words, paying $f_{5}$ per picol. ${ }^{115}$ Dorrepaal \& Co. had finally been restructured into the Dorrepaalsche Bank der Vorstenlanden.

However, this was not the end of the story. The Dorrepaalsche Bank continued to struggle with a shortage of capital. By the end of 1885 an additional credit of $f_{3}, 000,000$ was needed to finance its agricultural commitments. The NHM provided the money by concluding a new consignment deal. In July 1886 the company was bailed out again by the Dorrepaal family with $f$ 1,00o,ooo. One of the conditions was that Mirandolle, who had been sidelined when the Dorrepaalsche Bank was formed, became the new Director (De Bree 1928-1930: II 265-266; Bosma and Raben 2003: 253). ${ }^{116}$

Of course, these ad hoc solutions did not solve the chronic capital shortage of the Dorrepaalsche Bank. ${ }^{117}$ More drastic measures were

114 NA/KB 883: 71; BI/DJB 52 No. 51: 205-206; BI/DJB 52 No. 92: 487. The help offered by the NIS was continued for several years. In November 1886 its management wrote to all sugar manufacturers in the Principalities that it would again lower its freight rate for sugar transports with regard to the 1887 season. In practice this meant a reduction of transport costs per picol of sugar of up to $26 \%$ (NA/NHM 7963 ).

115 NA/KB 883: 96; BI/DJB 52 No. 92: 484, 497-498.

116 NA/KB 883: 162-168.

117 On 30 August 1886 the Semarang agent of the NHM confirmed the acute shortage of capital in a letter to Batavia. He had been informed that the Dorrepaalsche Bank used its working capital for all kinds of other purposes. (For instance, three factories accredited $f 475,000$ on 3 April 1886 had received only $f_{262,000}$ at the end of July.) The owners' discontent started to grow and he was confident that these relations could be taken over by the Factorij with relative ease (NA/NHM 2444 No. 456; Bosma and Raben 2003: 253). 
demanded. A reorganization plan was announced on 11 August which converted the Dorrepaalsche Bank into the Cultuurmaatschappij Dorrepaal. Shareholders and debenture holders were not enthusiastic and this sealed the company's fate. Suspension of payment was granted on 3 September 1886 for a period of one year. The firm faced a total loss of $f 7,000,000$. In September 1887, the management of the Dorrepaalsche Bank declared itself bankrupt. A new company by the name of Cultuurmaatschappij der Vorstenlanden (at some point the name Dorrepaal had been lost) would be its successor. Since only $30 \%$ was offered to pay for any outstanding debt of the dissolved Dorrepaalsche Bank, most creditors decided to participate in this new enterprise. On 1 March 1888 the Cultuurmaatschappij der Vorstenlanden was founded with total assets valued more than $f 6,000,000$ lower than its predecessor (Bosma and Raben 2003: 254; Helfferich 1914: 143-160).

The Dorrepaal family did not participate in this company. In early 1887 , it had established the Klattensche Cultuur Maatschappij into which the privately owned enterprises (i.e. the ones not included in the debt settlement) were absorbed. Mirandolle was in charge of product sales which he soon turned into a separate company. From 1 January 1889 the trading company Mirandolle Voûte \& Co., official representative of the Klattensche Cultuur Maatschappij, was in business in Semarang. ${ }^{118}$

\section{The Crisis Prolonged: Sing Liong \& Co.}

The commotion surrounding the financial reorganization of the agricultural export industry peaked in the first few months after the price of sugar plummeted (Colenbrander and Stokvis 1916-1917: II 144-147). Attention in the Netherlands was overwhelming. Newspapers reported frequently, if not daily, on the subject. A quick look at the issues of Dutch newspapers - e.g. Algemeen Handelsblad, De Nederlandsche Financier, Het Nieuws van den Dag, or De Amsterdammer - shows that during the last two months of 1884 and in early 1885 the crisis was considered hot news. ${ }^{119}$ Soon after interest started to subside and finally dwindled away. The crisis ceased to appear on the front pages. The different committees installed to solve the situation did their job and were subsequently dissolved. Once again, business was conducted behind closed doors.

118 NA/KB 883: 165-166.

119 See also NA/KB 916. 
The massive financial restructuring of the agrarian export sector did not bring an immediate end to the crisis. At first instance, the consequences for the import side of the economy appeared negligible. In 1884 the total number of trade bankruptcies was 55 against 58 in 1883. There was a general sense of optimism among European and Chinese import traders. Many shared the belief that the sugar crisis was a momentary deviation caused by short-term speculation on the part of wholesale exporters. Few foresaw the tenacity of the depression and no one predicted it to last well into the 189os (Rush 1990: 179-183). Statistical evidence published in 1889 shows how unwarranted the feeling of optimism was. The effects of the crisis had only been delayed and the import sector was hit by numerous bankruptcies (see Table 3.4).

Chinese traders figured prominently in this deteriorating situation. European wholesale traders experienced great problems in reclaiming their outstanding loans. Often less than $10 \%$ of extended credit could be retrieved. In $188775 \%$ of defaulting Chinese traders could not even accomplish that. Consequently, wholesale importers had to curtail their expenditures, not only because of outstanding debts, but also because money had become less available. The financial sector increasingly regulated its activities and the banks were more careful than ever in credit approval.

The wholesale import companies soon started to feel the shortage of cash. Among them was the trading firm Soesman \& Co. which suspended payment on 21 November 1886 after more than 50 years of commercial

Table 3.4. Trade bankruptcies in the Netherlands Indies, $1883-1887$.

\begin{tabular}{|c|c|c|c|c|}
\hline & \multirow{3}{*}{ Total } & \multicolumn{3}{|c|}{ Chinese bankruptcies } \\
\hline & & \multirow[b]{2}{*}{$\begin{array}{l}\% \text { of total } \\
\text { bankruptcies }\end{array}$} & \multicolumn{2}{|c|}{ retrieved debts } \\
\hline & & & $\begin{array}{l}\text { partially } \\
\text { retrieved }\end{array}$ & $\begin{array}{l}\text { less than } 10 \% \\
\text { retrieved }\end{array}$ \\
\hline 1883 & $5^{8}$ & $38(66 \%)$ & $36 \quad(95 \%)$ & $21(55 \%)$ \\
\hline 1884 & 55 & $38(69 \%)$ & $33 \quad(89 \%)$ & $17(45 \%)$ \\
\hline 1885 & 99 & $66(67 \%)$ & $64 \quad(97 \%)$ & $32(48 \%)$ \\
\hline 1886 & 113 & $77(68 \%)$ & $77(100 \%)$ & $31(40 \%)$ \\
\hline 1887 & 110 & $69(63 \%)$ & $17 \quad(25 \%)$ & $5 \quad(7 \%)$ \\
\hline
\end{tabular}

Source: De Indische Gids 111 (1889) 1083-1084. 
activity (Mansvelt 1938: Bijlage 1). ${ }^{120}$ Soesman \& Co. was a renowned and experienced import company in Central Java with a head office in Semarang and two branch offices in Solo and Yogyakarta. It had experienced no problems late 1884 and displayed no signs of payment difficulties. Still, it did not survive the crisis unscathed. At the end of 1885 the company closed its books with a total capital of $f 887,000$ of which $44 \%$ ( $f 386,000)$ had a short-term character. In other words, a significant percentage of its funds could be claimed by creditors at short notice. In addition, the company had extended credits to the amount of $f_{504,000}$. No harm was done as long as the instalments were paid on a regular basis. The situation changed rapidly in the first 10 months of 1886 . Soesman \& Co. suddenly experienced problems in payment from its debtors and could thus hardly meet the expiry dates of its own debts.

The explanation offered, illustrates the general economic circumstances in Java following the crisis of 1884 .

[...] the difficulties the firm finds itself in, can be attributed in principal to two causes, both of them a consequence of the current unfavourable circumstances.

1. the credit the company used to have at its disposal, is drawn back, which appears from the termination of deposits, whereas the facilities the company used to enjoy from houses here [trading companies in Semarang] when buying goods cannot be counted on anymore.

2. the debtors are paying less and less, manifesting itself particularly in the case of the indigenous princes and elite all involved in agricultural enterprises. ${ }^{121}$

From January to October 1886 average repayments of debtors amounted to approximately $f 28,000$ a month. The monthly sales figures on the other

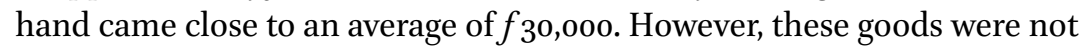
paid for in cash upon receiving them. In other words, extra credit of about $f$ 2,00o had been involuntarily extended whereas a contraction would have been more appropriate. No improvement was foreseeable and dissolving the company seemed the most sensible option. This course of action was justified, because:

[...] it offers more opportunity to act powerfully against debtors, more especially the indigenous princes and elite, so that important payments from their part can take place, without running the risk of losing their very profitable clientele in case of a continuation of the business. ${ }^{122}$

120 NA/NHM 7981 No. 241.

121 Ibidem.

122 Ibidem. 
Adverse external circumstances had made Soesman \& Co.'s position untenable. This happened with such speed that owners and creditors alike were taken by surprise. A number of internal measures were considered, like economizing on expenses or curtailing the field of operation, etc. Such arrangements would undoubtedly have given the company some breathing-space. The proposals were nonetheless rejected since it would take too much time to produce the required results. Creditors would soon start retrieving their loans instead of prolonging them for fear of losing their claims altogether.

The Chinese retail traders found themselves in a similar position. The situation in the Chineesche kamp (Chinese residential area) was therefore monitored closely. Bankers and traders paid scrupulous attention to any rumours regarding their Chinese clients. DJB recognized the need for more systematic retrieval and storage of information. Inspection of the agencies and their clientele was regularly conducted and had proven its value. DJB now started to pay even more attention to its clients' status. Over the years, agents had informed the head office about their clients in case of "certain changes" such as a delay in payment or rumours about a possible bankruptcy. This method had become outdated. The economic situation as well as the expansion of DJB's field of operation and its complex business dealings demanded more up-to-date information at immediate disposal.

In February 1890 the subject was raised by President S.B. Zeverijn. ${ }^{123}$ According to him more should be done to ensure adequate information retrieval. From now on all agents had to keep records of their clients' status in 'information books'. These should be sent to Batavia, where the head office intended to compile a register of all companies and traders with whom DJB did business. Any firm or person considered important enough to be a potential client were to be included as well. The register would provide an immediate overview of a client's financial position and greatly facilitate future decisions regarding proposed transactions. Zeverijn's suggestion was put into effect and within a few months the first information books from Makassar, Surabaya, and Semarang were recieved. ${ }^{124}$ The usefulness of the register proved itself in practice and

123 BI/DJB 57 No. 79: 290.

124 BI/DJB 58 No. 5: 16; BI/DJB 58 No. 14: 48; BI/DJB 58 No. 18: 61; BI/DJB 58 No. 32: 114. Unfortunately, the archive of DJB contained only the information book of Surabaya compiled in 1890 . Whether the other books have been lost, misplaced or deliberately destroyed during the Pacific War remains a matter of speculation. 
needed to be revised a decade later. In August 1900, the agents were instructed to compile new information books using a standard format with regard to both content and outward appearance. ${ }^{125}$

DJB's quest for information was only one attempt to enhance security. A refinement of regulations concerning the extension of credit was another. With bankruptcies rather common DJB was particularly aware of the need for sufficient surety. Each loan had to be covered to avoid financial risk. Obviously, this could not always be prevented, but the mistakes made in the case of the Chinese trading firm Sing Liong \& Co. made it clear that there was much room for improvement.

\section{Sing Liong \& Co.}

Around three o'clock in the morning on Sunday 11 June 1893 the inhabitants of Kampong Bahroe in Surabaya were rudely awakened by the sound of the tongtong, ${ }^{126}$ The warning signalled the outbreak of fire in one of the godowns located in their neighbourhood. When police and fire-brigade arrived on the scene, smoke and flames were bursting from the roof of the warehouse. With the flames spreading to other buildings the fire could develop into a full-blown blaze. The police managed to force the entrance and the fire could be extinguished before causing any serious damage. Soon it became obvious that arson was involved. Inside the warehouse divided into two godowns under the same roof - the air was permeated with the smell of petroleum. Upon closer inspection it was discovered that the wooden beams under the ceiling had been wrapped with gunny bags, soaked in petroleum, whereas the gutters of the building had been filled with petroleum as well. Even more disturbing was the fact that the adjacent godowns had also been smeared with petroleum. Had the fire not been detected so early very little could have been done. A disaster had been prevented by a stroke of luck.

Though the fire had started at the godown of Sing Liong \& Co., its owners - Kho Swie Siang and Kwa Kok Ing - had no part in it. The investigation pointed to another Chinese trader, The Yang Hie, whose godown was situated in the same building. The rice in store at this location had been insured by him for $f 155,000$. A recount showed that the amount of rice present was only worth $f_{3}, 000$. The Yang Hie was detained upon suspicion

125 BI/DJB 74 No. 41: 225 .

126 In most instances a wooden block hammered on, to alarm people in case of distress. 
of insurance fraud, but denied all charges brought against him. However, it took the police less than a week to find out that he had indeed masterminded the arson. Repeated questioning of The Yang Hie's Chinese employees led to the arrest of two Madurese day labourers, who subsequently confessed to the crime. According to their statements, they had been promised $f 300$ each in advance and $f 500$ after the job had been done. The Yang Hie had provided them with the petroleum and given specific instructions how to proceed. In order to avoid suspicion, the fire had to be lit at Sing Liong \& Co. by breaking and entering through the roof. With this kind of evidence, The Yang Hie's denial was hardly convincing. The judicial process did not take long and in September 1893 The Yang Hie and his accomplices were convicted to fifteen years of hard labour. ${ }^{127}$

When the DJB head office first learned of the events in Surabaya, the Directors did not seem worried. President and Directors discussed the situation on 19 June 1893 after having received the necessary information from the Surabaya agency. ${ }^{128}$ According to the agent - H.J.J. Hepp - the fire had done little damage and what damage there was could be reclaimed from the insurance companies. This applied specifically to Sing Liong \& Co., which had been advanced $f$ 73,00o with rice as collateral. The President added that DJB had no engagement with The Yang Hie and no financial losses could be incurred from his criminal actions. But Hepp had been less than frank when writing that the advanced sum was fully covered. The day after the fire he had become aware of a deficit in the quantity of rice stored at the godown of Sing Liong \& Co. ${ }^{129}$ Instead of reporting this, he bought himself time by ordering a recount. The reason for this will become clear in the following account which takes us back to the scene right after the outbreak of the fire.

Despite the early hour many people could be found in the street shortly after the alarm had been given. Among the curious crowd gathered to watch the fire, one person was professionally interested in the spectacle. V. Eweg had only recently been employed at the Surabaya agency of DJB with the task of guarding the collateral on the basis of which credit had been extended. He had been alerted by J.K. Herman, the bewaarder (keeper) of the godowns, who had come to his house within hours after

\footnotetext{
127 BI/DJB 63 No. 26: 129; BI/DJB 63 No. 63: 324; SH, 12-06-1893, 13-06-1893, 14-06-1893, 19-06-1893, 21-06-1893, 23-06-1893.

128 BI/DJB 63 No. 26: 129.

129 BI/DJB 63 No. 38: 202-206.
} 
the fire. Upon hearing the news Eweg left as soon as possible to have a look himself. ${ }^{130}$ Upon arrival he realized there was little he could do besides notifying his superiors. The next day Eweg visited the storage of The Yang Hie and Sing Liong \& Co. again accompanied by Hepp himself. A first glance at the sacks of rice, damaged by petroleum and water, convinced them that something was seriously wrong. Clearly, there was a deficit but the disorder inside the godown did not permit an estimate at that time. The only thing to do was to order a recount and find out exactly how much was missing.

A deficit of minor proportion was not uncommon. In general the kind of loan Sing Liong \& Co. had been given, was only authorized on a number of conditions. First and foremost, there should always be a $20 \%$ surplus value of products and/or goods against the money extended. ${ }^{131}$ In other words, the $f 73,000$ credit from $\mathrm{DJB}$, had to be covered by an amount of rice with an estimated market value of $f 91,250$. With the prevalent market price in Surabaya at approximately $f$ 1,000 for 300 picols of rice, there should be 27,00o picols of rice. ${ }^{132}$ The question was whether this amount was actually present. The recount carried out under the supervision of Eweg took some time and was not finished until 28 June 1893. The final outcome was worse than expected. Sing Liong \& Co. was over $40 \%$ short, which amounted to 11,00o picols of rice with an estimated market value of $f 37,000 .{ }^{133}$ This entailed a breach of contract and DJB would normally terminate the existing agreement and demand an immediate reimbursement of the loan. ${ }^{134}$ Unfortunately, this procedure could not be followed, for Sing Liong \& Co. had been declared bankrupt two days before on 26 June $1893 .{ }^{135}$

President and Directors of DJB first learnt of the deficit and possible fraud of Sing Liong \& Co. in a telegram informing them of the firm's bankruptcy. In a rather angry reply additional information was urgently requested. Within days the events leading up to the present situation were

\footnotetext{
130 Ibidem.

131 BI/DJB 63 No. 37: 194.

132 Soerabaiasch Handelsblad (SH), 14-06-1893.

133 BI/DJB 63 No. 29: 145; BI/DJB 63 No. $30: 150$.

134 This is what happened when Eweg reported a deficit in the godown of Ong Kong Wan on 17 May 1893. Ong Kong Wan had been advanced $f 15,000$, but upon inspection it turned out only about one-third of this amount was covered. DJB immediately cancelled the contract and demanded to be reimbursed before the end of May. Ong Kong Wan could only acquiesce and repaid the loan by 7 June in two instalments of $f_{12,000}$ and $f_{3}, 000$ (BI/ DJB 63 No. 38: 203).

135 BI/DJB 63 No. 28: 141; $S H, 26-06-1893$.
} 
pieced together. ${ }^{136}$ It transpired that Kho Swie Siang and Kwa Kok Ing had fallen out with each other. Kwa Kok Ing, who suffered from an illness, accused his associate of embezzling the company's money and financial records during his absence. In an effort to secure his property, he had seized the rice godown by court order whereupon Kho Swie Siang had filed for bankruptcy. Reimbursement from the two partners in the Chinese firm was now impossible. ${ }^{137}$ The only person who could be held financially accountable, was J.K. Herman. As keeper of Sing Liong \& Co's collateral, he had failed to make sure that nothing was moved in or out of the godown without proper registration. However, with hardly anything to his name, the sale of his assets would not be enough to compensate DJB. In short, a financial loss could not be avoided and the resulting damage had to be covered by DJB itself.

The head office was not content to leave it at this and pressed for firm action. Negligence was suspected and for good reason. The local newspapers of Surabaya were read in Batavia with great interest. The Soerabaiasch Handelsblad $(\mathrm{SH})$ reported almost daily about the fire and its aftermath. Its coverage started with an article on 12 June and DJB's management must have been extremely intrigued by the concluding line:

Conspicuously, from a writing desk in the godown all the books, papers, etc. had disappeared. Saved in time or stolen, one wonders. ${ }^{138}$

As a result of the following investigation, Kho Swie Siang was arrested. The company's records were never retrieved and Eweg's attempts to obtain the godown's registry remained fruitless. ${ }^{139}$ When exactly the rice had been moved and who had been involved could not be ascertained. Agent Hepp was getting increasingly worried. The head office was running out of patience and not prepared to accept more delay. Hepp's delaying tactics can be understood when we take his nomination as Director of

\footnotetext{
136 BI/DJB 63 No. 29: 144-146; BI/DJB 63 No. 30: 150-152.

137 Ever since 1855 the Netherlands Indies judicial system allowed Chinese businessmen to file for bankruptcy themselves. This was a common feature in the trading sector at large. Approximately three quarters of the total number of pronounced bankruptcies in the Netherlands Indies for the period $1883-1887$ had been initiated by the defaulter himself (1883: 74\%; 1884: 76\%; 1885: 71\%; 1886: 76\%; 1887: 86\%). This practice was a source of aggravation for many European wholesale traders, fearing fraudulent intentions from the side of the Chinese. As late as August 1892, J.W. Young - working as a translator of Chinese in Semarang - had fulminated against it, pleading for a change in the law in order to offer more protection against suspected Chinese bankruptcies (Meeter 1881:64-64, 67; De Indische Gids (IG) 111 (1889) 1083-1084; TNI 212 (1892) 244-245).

138 SH, 12-06-1893.

139 BI/DJB 63 No. 38: 204.
} 
DJB in consideration. His successor had already arrived in Surabaya and everything had been arranged for his departure to Batavia on 3 July. The shock must have been great when he received a telegram on 30 June telling him to remain in Surabaya. ${ }^{140}$

Hepp was instructed to wait for a list of questions pertaining to the matter of Sing Liong \& Co. drawn up by President and Directors. The earlier dismissal of Herman had not sufficed to soothe the matter. Since the agent was ultimately responsible, Hepp probably feared a reprimand or even worse. He was fully aware of the fact that he had not been installed yet as Director of DJB. With his career in jeopardy Hepp found an easy scapegoat in the person of Eweg. So far Eweg's conduct had not been criticised and Hepp even suggested appointing him in the former position of Herman. Suddenly, Hepp's favourable opinion of Eweg changed. ${ }^{141} \mathrm{He}$ accused Eweg of having played an ambiguous role and of having tried to mislead him. Eweg tried to refute these allegations. According to him he had informed the deputy agent E.M.A. Noothout twice about a possible deficit at Sing Liong \& Co.'s, but to no avail. Noothout flatly denied this and Eweg was not believed. In fact, it hardly mattered whether Eweg told the truth or not, because he had compromised himself to such an extent that his pleas seemed unconvincing. ${ }^{142}$

Eweg had been employed by DJB less than a year. He and his family had arrived in Surabaya in 1892. Faced with the costs of renting and furnishing a place to live, Eweg ran into financial problems. He decided to borrow money from a befriended Chinese trader. It turned out that he had taken up a private loan of $f 250$ with none other than Kwa Kok Ing. This was deemed unacceptable. Eweg was fired instantly, although there remained some doubt whether or not he had really conspired with Sing Liong \& Co. The President and Directors even expressed pity for him and his family. No charges were brought against him and an earlier advance on his salary was written off. In addition, he was given six weeks pay. In the case of deputy agent Noothout inquiries were made as to his suspected negligent behaviour, but no further disciplinary measures were taken. ${ }^{143}$ Hepp got

140 BI/DJB 63 No. 30: 151.

141 BI/DJB 63 No. 31: 153-154.

142 BI/DJB 63 No. 33: 166; BI/DJB 63 No. 38: 202.

143 Nevertheless, Noothout had been compromised by the whole affair and rumours originating from Eweg - concerning his alleged shameful behaviour started to circulate in Surabaya. In the end, his once promising career at DJB proved to be short-lived, because in 1894 his employment was terminated (BI/DJB 63 No. 37: 193-194; Regeeringsalmanak voor Nederlandsch-Indië 1894, 1895). 
his promotion and would serve as Director of DJB from 1893 till 1898 (De Bree 1928-1930: II 576-577). Finally, Kho Swie Siang was found guilty of embezzlement and sentenced to three years of hard labour. No charges were pressed against his associate Kwa Hok Ing to the regret of DJB's new representative in Surabaya, who attributed the whole affair to mismanagement of his predecessor. ${ }^{144}$

The fire of Sunday 11 June 1893 saw not only The Yang Hie exposed as an impostor, but also the owner(s) of the trading firm Sing Liong \& Co. Had it not been for the failed arson attempt, these fraudulent actions might have gone unheeded. The same applied for the apparent negligence of several of DJB's employees in Surabaya, who had failed to perform their duties adequately. As a result, jobs were lost, reputations tarnished and a financial write-off had to be accepted.

In reaction to all this, the regulations for credit extension were severely scrutinized. Discussions regarding this subject had been held before. Argumentation had centred around the kind of credit DJB could provide. DJB's statutes only allowed trading activities to be supported, but sometimes local circumstances prompted a different approach. In 1862 longlasting credit arrangements with agricultural and industrial enterprises had therefore run as high as $f 1,500,000$. The Netherlands Indies government had intervened and DJB's management in Batavia promised to mend its ways. However, acknowledging the problem fell short of effectively dealing with it. Knowing the importance of local expertise DJB was not willing to curtail the independence of its agencies too much. A rather vague guideline was formulated in 1876 which left sufficient room to accommodate requests not fitting the standard format. ${ }^{145}$

The experience with Sing Liong \& Co. made it abundantly clear that an overhaul of credit regulations was urgently needed. The surplus value of the collateral was raised from $20 \%$ to $30 \% .{ }^{146}$ There followed a long and drawn-out debate about supervision which would last until 1895 (see Figure 3.1). The main question was how to anticipate changes influencing the conditions under which credit had been extended. An improvement in monitoring was emphasized. The job of controller (controleur) was created to achieve this and a detailed and standardised set of instructions for both controller and keeper replaced the old ad hoc

\footnotetext{
144 BI/DJB 65 No. 37: 107.

145 BI/DJB 43 No. 28: 137, 139-140; BI/DJB 43 No. 47: 295-309.

146 BI/DJB 63 No. 37: 194.
} 


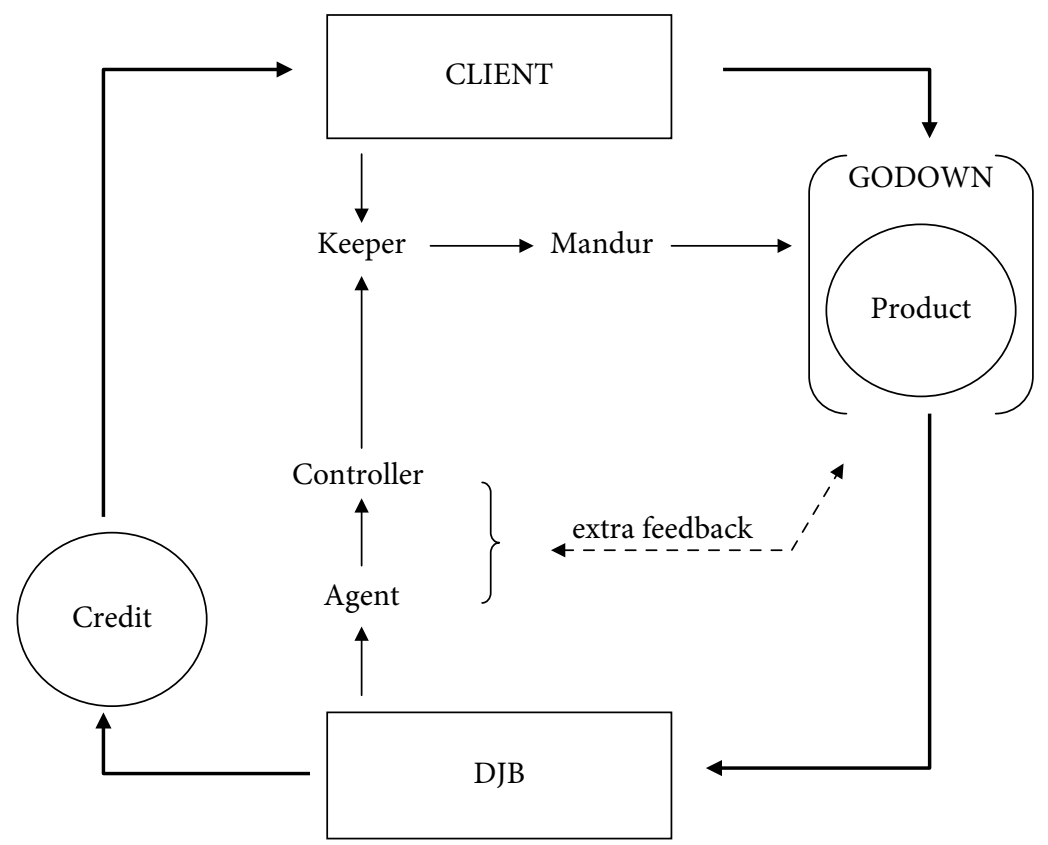

The flow of credit on the basis of products (agrarian or otherwise) is represented by the black arrows running clockwise. The monitoring function is represented by the thin lines with the arrows pointing to the levels under supervision. The dotted line shows the extra feedback mechanism, in order to achieve an even higher level of control.

\section{GODOWN}

CLIENT

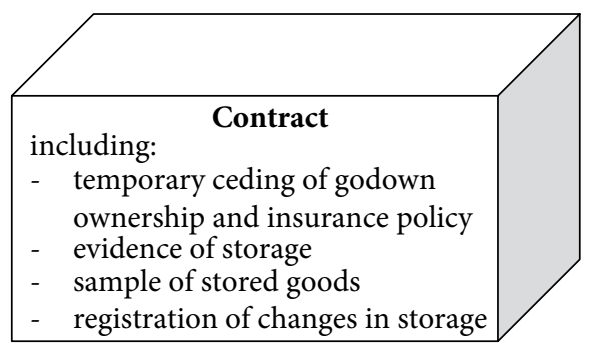

DJB

Fig. 3.1. Credit arrangements with improved monitoring function.

Source: BI/DJB 67 No. 10: 47, 63-91.

guidelines. ${ }^{147}$ Attention was also paid to the period preceding the signing of the contract. A whole array of certified documents was required before parties would sign the deal in the presence of a notary.

147 The controleur was an employee of DJB specifically tasked with the supervision of any outstanding credit including the conditions under which it was extended. This 
Nevertheless, it remained difficult to find a format applicable to all circumstances. This was not even desired by DJB's management. In reaction to a proposition made by his successor in Surabaya, Director Hepp warned against the tendency to regulate the whole process in the smallest detail.

It seems to me, that the Agent wants to elicit instructions for all conceivable circumstances, so that he is always covered and nothing has to be left to his own initiative. [...] I consider such generalization inappropriate, it should be left to the Agent to act according to the circumstances. ${ }^{148}$

In his opinion it was simply impossible to anticipate every conceivable incident. Each agent had to take his responsibility. Hepp himself elaborated on this by remarking that:

It will probably be impossible to conduct business without any risk, no matter how small, and without any confidence in his helpers and subordinates. ${ }^{149}$

A true, but somewhat puzzling statement, when seen in the light of his earlier opportunistic stance.

By implementing the new regulations DJB found itself better equipped against future bankruptcies. This strategy of risk reduction was not infallible, but seems to have met its purpose reasonably well. The trading sector naturally aspired to similar regulations, enabling them to guard their interests more efficiently. But even the biggest trading companies could not act as independently as DJB. Operating in a far more competitive business environment, a significant reduction of risk could not be achieved by internal measures only. Few acknowledged this outright and attempts to join forces were only made when the situation really demanded it. It would take until 1897 before such an instance occurred. When a wave of Chinese bankruptcies threatened to undermine the trading sector of Surabaya action was finally taken. In the following chapter this event and the background against which it took place will serve to illustrate the challenges faced by the trading business at the turn of the century.

entailed much paperwork, but as part of his responsibilities he would also inspect godowns paying close attention to the way the bewaarder performed his duties.

148 BI/DJB 67 No. 10: 87.

149 BI/DJB 67 No. 10: 89 . 